Capacity Building Activities to Strengthen Agroforestry as a Sustainable Economic Alternative in the Orangutan Habitat Conservation Program of Batang Toru, North Sumatra

Endri Martini, Jusupta Tarigan, James Roshetko, Gerhard Manurung, Iwan Kurniawan, Joel Tukan, Suseno Budidarsono, Melissa Abdo, and Meine van Noordwijk 



\section{Capacity Building Activities to Strengthen Agroforestry as a Sustainable Economic Alternative in the Orangutan Habitat Conservation Program of Batang Toru, North Sumatra}

Endri Martini, Jusupta Tarigan, James Roshetko, Gerhard Manurung, Iwan Kurniawan, Joel Tukan, Suseno Budidarsono, Melissa Abdo, and Meine van Noordwijk 


\section{(7) \\ World Agroforestry Centre \\ TRANSFORMING LIVES AND LANDSCAPES}

\section{Correct citation:}

Martini, E., J. Tarigan, J. Roshetko, G. Manurung, I. Kurniawan, J. Tukan, S. Budidarsono, M. Abdo and M. van Noordwijk. 2008. Capacity Building Activities to Strengthen Agroforestry as Sustainable Economic Alternative in the Orangutan Habitat Conservation Program of Batang Toru, North Sumatra. WP number 61. Bogor, Indonesia, World Agroforestry Centre - ICRAF, SEA Regional Office. 57p.

Titles in the Working Paper Series aim to disseminate interim results on agroforestry research and practices and stimulate feedback from the scientific community. Other publication series from the World Agroforestry Centre include: Agroforestry Perspectives, Technical Manuals and Occasional Papers.

Published by the World Agroforestry Centre

United Nations Avenue

PO Box 30677, GPO 00100

Nairobi, Kenya

Tel: +254(0)20 7224000, via USA +1 6508336645

Fax: +254(0)20 7224001, via USA +1 6508336646

Email: icraf@cgiar.org

Internet: www.worldagroforestry.org

(C) World Agroforestry Centre 2008

Working Paper nr 61

\section{Maps:}

Ekadinnata, A. 2007, Result of Landsat 2006 Image Analysis. ICRAF Spatial Analyst Unit Team. Bogor.

The views expressed in this publication are those of the author(s) and not necessarily those of the World Agroforestry Centre.

Articles appearing in this publication may be quoted or reproduced without charge, provided the source is acknowledged.

All images remain the sole property of their source and may not be used for any purpose without written permission of the source.

\section{Disclaimer for copyright page:}

This program and activities reported in this document were implemented with the support the United States Agency for International Development (USAID), Rural Environmental Management Program, Jakarta Mission. The opinions expressed herein are those of the authors and do not necessarily reflect the views of USAID 


\section{About the authors}

\section{Endri Martini}

Worked as ICRAF staff for the Batang Toru Orangutan project as Agroforestry Tree Specialist. She worked directly with the community in building farmers capacity on agricultural techniques in enhancing agroforest productivity. Contact: e.martini@cgiar.org Jusupta Tarigan

Worked as ICRAF staff for the Batang Toru Orangutan project as Agroforest Livelihood Specialist. He worked directly with the community in building farmers capacity and awareness on livelihood-conservation linkage. Contact: j.tarigan@cgiar.org

\section{James Roshetko}

Winrock International scientist seconded to ICRAF's Southeast Asia programme in Indonesia as the Leader of the Trees and Markets Unit. He was the coordinator of ICRAF Batang Toru activities. Contact: j.roshetko@cgiar.org

\section{Gerhard Manurung}

Working at ICRAF as Agroforestry Tree Specialist, was involved in the Batang Toru project for consultation and training in improving farmers' agroforest farming systems.

Contact: g.manurung@cgiar.org

\section{Iwan Kurniawan}

Working at ICRAF as Marketing Specialist, was involved in the Batang Toru project for consultation and training in enhancing farmers awareness on marketing their agroforest products. Contact: k.iwan@cgiar.org

\section{Joel Tukan}

Marketing specialist who was involved in the ICRAF Batang Toru activities, in the first phase of the project. He is currently working at the Australian embassy.

Contact: joel.tukan@ausaid.gov.au

\section{Suseno Budidarsono}

ICRAF Research Officer involved in the ICRAF Batang Toru activities, particularly in the preliminary social economy survey. Contact: s.budidarsono@cgiar.org 


\section{Melissa Abdo}

Volunteer from Winrock International Farmer-to-farmer program who is also an environmental resource management and conservation specialist. She was involved in ICRAF Batang Toru project for providing recommendations and inputs to the process building conservation-livelihood linkage at the community level.

Contact: mabdo002@gmail.com

\section{Meine van Noordwijk}

Principal scientist who is also the current regional coordinator of ICRAF South East Asia. He provided consultation and suggestions in various aspects of the ICRAF Batang Toru activities. Contact: m.vannoordwijk@cgiar.org. 


\section{Abstract}

Positive incentives for appropriate land management need to be created to counter the incentives for negative change if we are going to preserve orangutans by conserving their habitat in Batang Toru area. Working with community members and other local partners to develop new ways for them to earn income without disturbing the forest or the orangutans, may provide win-win solution in the orangutan conservation program. In that context, ICRAF and Winrock International see a number of non-timber forest products (NTFPs) that are produced in Batang Toru forest systems (e.g. mixed tree gardens, agroforests, and forests) as having potential to diversify and secure viable livelihood options for the people of Batang Toru. In all those land use systems (mixed tree gardens, agroforests, and natural forests) planning and management is limited. Thus, improvements in managing the species/crops and developing market linkages could benefit the productivity, profitability and sustainability of these systems.

Community strategies were developed to provide improved technical approaches that enhanced the productivity and/or profitability of non timber forest products (NTFP) in their agroforestry livelihood systems compatible with the protection of orangutan habitat and to catalyze the communities' capacity for marketing those products. A series of training events became the corner stone for building the farmers' capacity to manage their agroforest garden into more productive, market oriented and environmentally friendly ways. The trainings were conducted by ICRAF, Winrock International and local trainers in 5 selected villages where the community had helped set the agenda. Training series were divided into 3 major areas (i) Building technical capacity related to rubber, cocoa and aren (the three main agricultural commodities in the selected villages) and livestock, (ii) Building capacity in marketing agroforest products, and (iii) Building capacity on livelihood-conservation awareness.

Farmers are very appreciative and greatly benefited of the technical support provide by ICRAF and Winrock over the year and a half period. The support enabled farmers to greatly enhance their technical knowledge and capacity. Of the activities conducted, those related to rubber management and production had the greatest impact.

\section{Keywords:}

agroforests, cacao, capacity building conservation, livelihood, rubber, sugar palm (aren), smallholder farmers 


\section{Acknowledgements}

A number of organizations and individuals provided assistance to make this work successful. The authors would like to thank: Winrock International's United States Agency for International Development (USAID)-funded John Ogonowski Farmer to Farmer Program and specifically Dr. Greg Fonsah, Ms. Nancy Morey, and Mr. Juan Guzman; Mr. Gunarif, Andalas University, Padang; farmer specialists Lam Lam Tarigan of Karo subdistrict, North Sumatra and Arifin Khaeran of Sibabangun subdistrict; rubber pathologist Suyatno of Sungai Putih Rubber Research Station; and all the participating farmers in the villages of Sibulanbulan, Sitandiang, WEK I, Hutagurgur, and Aek Nabara. Additionally, we thank the staff of Conservation International Indonesia for productive and successful collaboration and the USAID Jakarta Mission for supporting the Development of Collaborative Orangutan Habitat Protection in Batang Toru Watershed, North Sumatra Project through which this work was implemented. 


\section{Contents}

Rationale vii

Steps To Catalyze Agroforest As A Source For Sustainable Conservation-Based Livelihood 3

Capacity Building Activities......................................................................................6

Conclusion/recommendations ...................................................................................... 23

Appendix 1. Training series on Clonal Rubber Seedlings Production in Batang Toru area

Appendix 2. Training on agroforest garden management: replanting techniques that can be applied in Batang Toru area

Appendix 3. Training on rubber pest and disease handling in agroforests in Batang Toru area

Appendix 4. Training on rubber tapping management in agroforest in

Batang Toru area 50

Appendix 5. Information collected during the sugar palm training. 52 Appendix 6. Estimated agroforest productivity per village based on FGD results

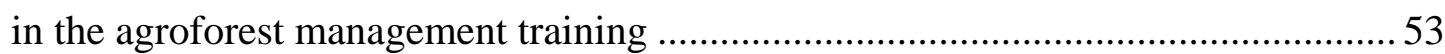

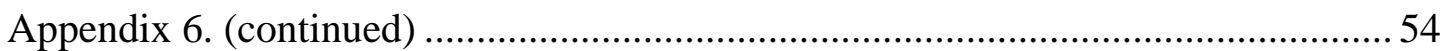

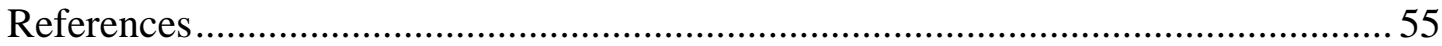




\section{List Of Figures}

Figure 1. Steps of activities in promoting agroforest as a source for sustainable conservation-based livelihood in Batang Toru area ................................................ 3

Figure 2. Land use classification of the five focus villages in Batang Toru area.................... 4

Figure 3. Linkages between livelihood and conservation in the context of nature resources management (Solid arrows indicate direct linkages, dashed arrows indicate

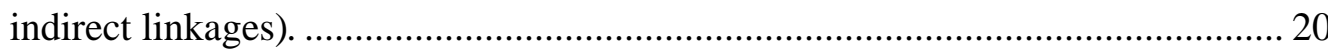

Figure 4. Scheme of Farmer to Farmer transfer knowledge process in producing clonal rubber in Batang Toru program............................................................................... 37

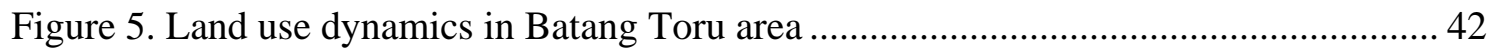

Figure 6. Rubber tree spacing alternative technique in garden rejuvenation by clear cut

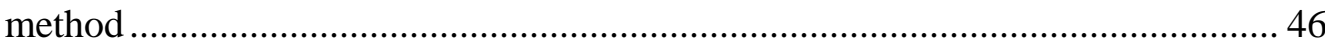

Figure 7. Example of scenario 2 replanting method based on the size of the gap and tree crown.

\section{List Of Tables}

Table 1. First two-months process of the farmer group formation in Batang Toru area 7

Table 2. Farmer groups status in Batang Toru area after one year formation process ........... 8

Table 3. Questions asked by the farmers and traders in the cacao training in Batang Toru

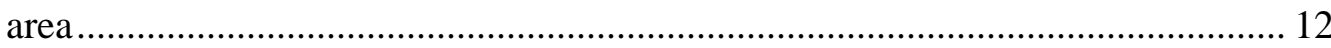

Table 4. Activities related to rootstock rubber nursery construction in Batang Toru area ... 30

Table 5. Global monthly progress on entres garden construction generally in all focus villages in Batang Toru area ............................................................................. 32

Table 6. Participants of the grafting training in five focused villages in Batang Toru area. 35

Table 7. Grafting training schedule that was conducted in Batang Toru area..... 35

Table 8. Number of rubber entres (scions) and its clone types that were distributed to each focus village in Batang Toru area

Table 9. Number of clonal seedlings produced from each focus village in Batang Toru area 


\section{Acronyms}

$\begin{array}{ll}\text { ICRAF } & \text { International Centre of Research in Agroforestry } \\ \text { USAID } & \text { United States Agency for International Development } \\ \text { NTFP } & \text { Non Timber Forest Product } \\ \text { CII } & \text { Conservation International Indonesia } \\ \text { BKSDA } & \text { Balai Konservasi Sumber Daya Alam } \\ \text { FG } & \text { Farmer Group } \\ \text { RMA } & \text { Rapid Market Assessment } \\ \text { KKP } & \text { Kesepakatan Konservasi dan Penghidupan }\end{array}$




\section{Rationale}

Batang Toru, located in the northern part of Sumatra, is one of the few remaining areas that support populations of the Sumatran orangutan (Pongo abelii). The existence of an orangutan population of 400 in the area was documented through a Population and Habitat Viability Assessment (PHVA) (Singleton et. al., 2004). Recent studies estimate that the population may be 380 at the current time (Sitaparasti, 2007). Although the Batang Toru orangutan population is small, its threat from habitat loss is relatively low (below 2\% annually). This low rate of habitat loss is the result of topographic features that limit access and, most importantly, of traditional indigenous forest management systems that are sustainable and value healthy environments. Besides orangutans, the Batang Toru forest is also rich with other endemic plant and animal species (e.g. Dipterocarpaceae species (Shorea spp., Anisoptera spp., Dipterocarpus spp.) and Sumatran tiger (Panthera tigris sumatrae)). To the present time the gradient of land use systems practiced by local communities in Batang Toru have been compatible with conservation of the area's unique and globally important biodiversity. However, in the future, the expanding human population of Batang Toru may threaten the forest and all of its components, if suitable livelihoods option are not identified and developed. Positive incentives to counter unsustainable forest use are need to be created if we are going to conserve orangutans and their habitat in Batang Toru area. We need to work with community members and other local partners to develop new ways for them to earn income without disturbing the forest or the orangutans. In that context, we see a number of nontimber forest products (NTFPs) that are produced in Batang Toru forest systems as having potential to diversify and secure viable livelihood options for the people of Batang Toru.

Currently, there are 27,906 $\mathrm{HH}$ in 251 villages who depend on 91,400 ha of Batang Toru forested area. A long history of sustainable forest resource management by local communities comprise a gradient of land use intensities ranging from mixed tree gardens (kebun campur) where species composition is largely controlled by farmers and management is intermediate, to natural forests where impact from human intervention is light with small quantities of products harvested. In between are various types to agroforests (forest farming systems) where human management favors plant species that provide useful/valuable products but management remains extension rather than intensive. The primary products from the mixed tree gardens of Batang Toru are rubber (Hevea brasiliensis), cacao (Theobroma cacao) and, in some villages, sugar palm (Arenga pinnata). These crops are the main source of on-farm family subsistence/income. In the natural forests and agroforests, plant species (which may be domesticated or semi-domesticated) that are important or hold potential include: gaharu (Aquillaria sp), benzoin (Styrax benzoin), durian (Durio zibethinus), petai (Parkia speciosa), nilam (Pogostemon cablin), and flowers (orchids and Nepenthes). The products from these species may be used for home consumption or sold in local/provincial markets. In all three land use systems (mixed tree gardens, agroforests, and natural forests) planning and management is limited. Improvements in managing the species/crops and developing market linkages could benefit the productivity, profitability and sustainability of these systems. Thus, community livelihood-conservation strategies need to be developed to identify/provide technical and marketing services/improvements to enhance the productivity/profitability of NTFPs and the productivity of their agroforestry systems. . 
The process in assisting local communities to conceptualize livelihood-conservation enhancement strategies for the protection of orangutan habitat and enhancing local people livelihood in Batang Toru area, was implemented over a 1.5 year period (2006-mid 2007) through the USAID-funded (United States Agency for International Development) project: Development of collaborative orangutan habitat protection in Batang Toru watershed, North Sumatra. The project is implemented by Conservation International Indonesia (CII), the World Agroforestry Centre (ICRAF), and Winrock International. Conservation International Indonesia focused on biophysics data collection and policy aspects, ICRAF and Winrock worked with local communities and local government agencies to develop local conservationlivelihood strategies that provide frameworks for: i) recognizing communities traditional role in conserving natural resources; ii) recognizing which local agricultural/forest livelihood systems are compatible with environmental conservation; and iii) strengthening communities/other stakeholders understanding/commitment to conservation as an approach to protect the environmental services (biodiversity, watersheds and carbon stocks). The frameworks were implemented through participatory community activities facilitated by ICRAF, Winrock and partners, as described in more detail in this working paper. 


\section{Steps To Catalyze Agroforest As A Source For Sustainable Conservation-Based Livelihood}

Steps to promote agroforest as a source for the sustainable conservation-based livelihood (Figure 1.) began with a socioeconomic survey conducted through a series of participatory rapid assessments. The purpose of the socioeconomic survey was to gain in-depth knowledge of the livelihood systems and to identify potential incentives that motivate the local community towards conservation-oriented activities. The survey included inventory of farmers' tree-based land use system (agroforests).

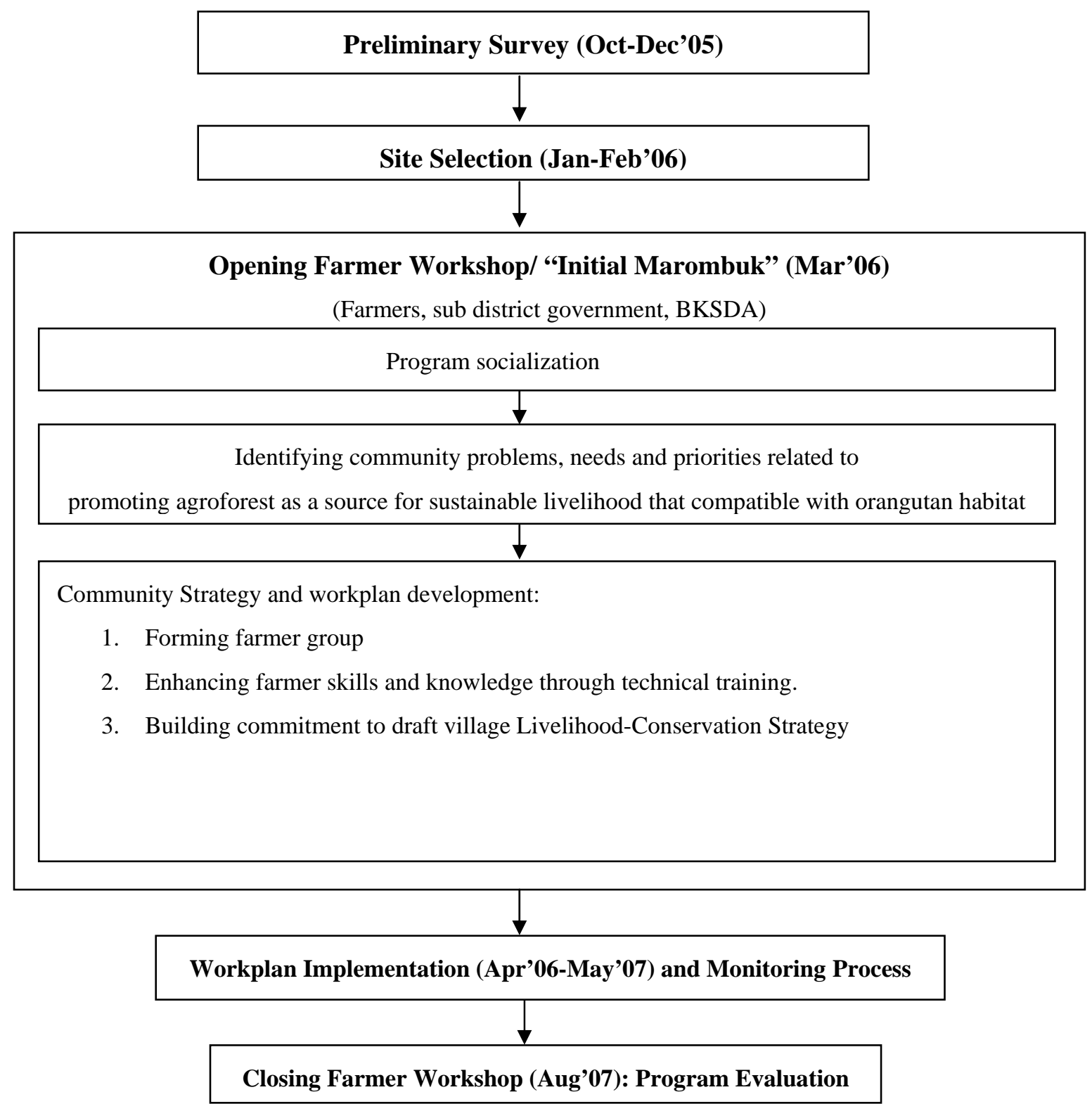

Figure 1. Steps of activities in promoting agroforest as a source for sustainable conservation-based livelihood in Batang Toru area 
Results of the socioeconomic survey and the preliminary orangutan distribution survey (conducted by CII) were used to develop the criteria for site selection. Through discussions with other stakeholders at a regional workshop held in January 2006, ICRAF and CII agreed to use the following site selection criteria:

a. Village adjacent to the forested area where orangutan still exists (as documented by the preliminary survey conducted by CII),

b. Accessible to other villages (to support the multiplier effect to other villages),

c. Village with productive agroforests that are currently used as a primary source of livelihood,

d. Community willingness to participate in the program and improve the productivity of their agroforestry systems.

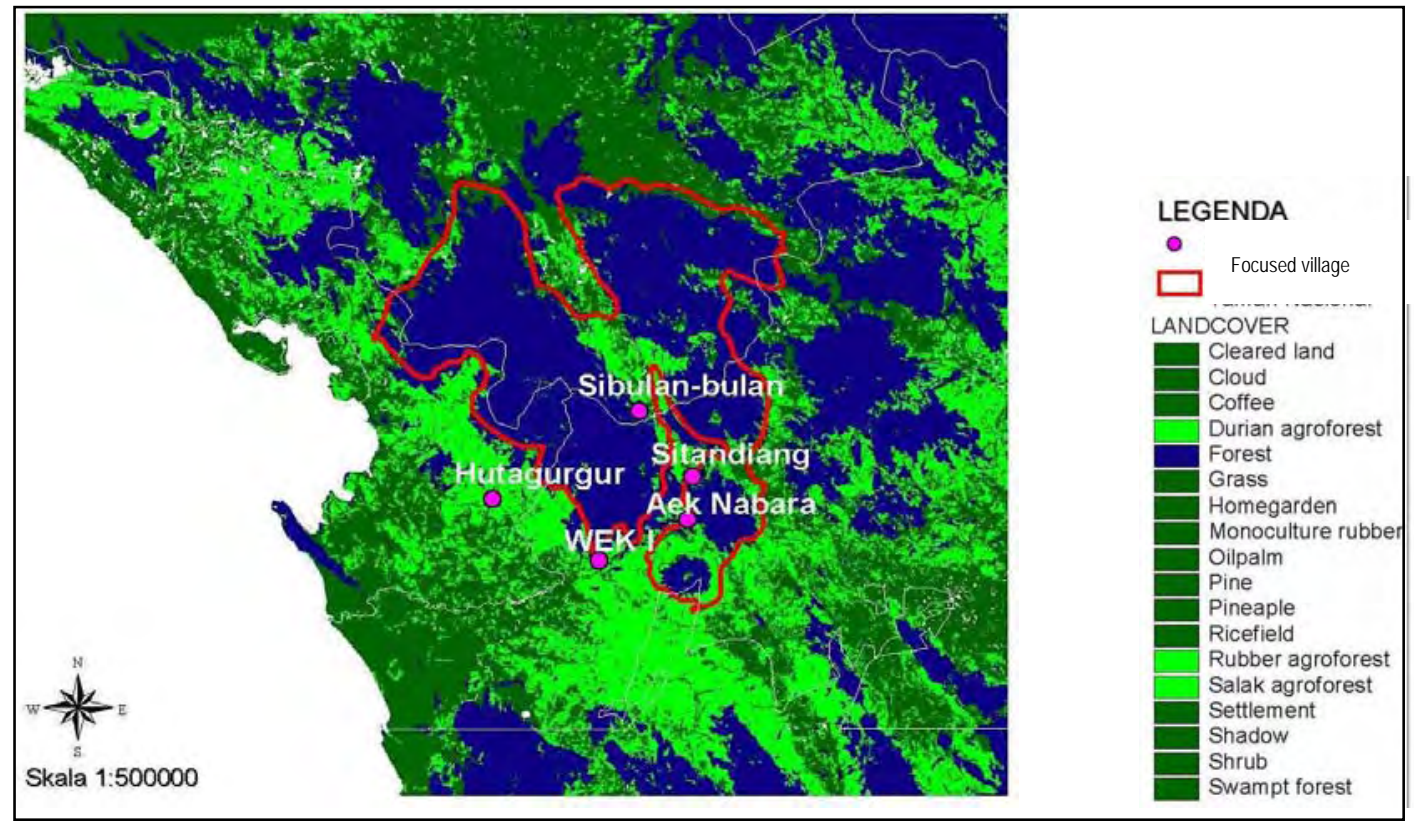

Note: Forest covered 43,26\% of the area, Agroforests 27,53\% and others land use types 29,21\%

Figure 2. Land use classification of the five focus villages in Batang Toru area

From 251 villages in the 3 districts, we selected 5 focal villages (Figure 2.):

a. Sibulan-bulan village, Purba Tua subdistrict, North Tapanuli district

b. Village Sitandiang, Subdistrict Sipirok, South Tapanuli district

c. Lorong Ulu Ala, Kel. WEK I, Subdistrict Batang Toru, South Tapanuli district

d. Village Hutagurgur, Subdistrict Sibabangun, Central Tapanuli district

e. Village Aek Nabara, Subdistrict Marancar, South Tapanuli district

After the sites were selected, an Opening Farmer Workshop (Marombuk) was conducted to identify community's problems, priorities and needs related to developing agroforests as a sustainable economy alternative. Fifty-four individuals participated in the 3 days workshop. Participants included representatives of focal villages, subdistrict governments, NGOs, and 
the Natural Resource Conservation Bureau. The output of the workshop was a strategy and workplans for 18 months. In the Marombuk, the attendees agreed that capacity building through farmer group formation and a series of training activities was the main strategy to enhance productivity of agroforest systems while also maintaining their conservation value. The strategy formulated during the Marombuk was implemented from April 2006 to May 2007, and facilitated by ICRAF, CI, Winrock International, Rubber Research Institute and local experts. Performance of the strategy implementation was evaluated at the end of the program, and a monitoring mechanism was developed to increase the chance of continuity of activities that had been initiated by the program. This report provides a rather detailed account of the activities and lessons learnt, to allow comparison with activities elsewhere. 


\section{Capacity Building Activities}

\section{Farmer Group Formation}

The formation of 'farmer groups' (FGs) provides a medium to share experiences and lessons between farmers and also to access new knowledge and technology from outside the village. Before the program began, no active farmer group existed in any of the focal villages, thus farmer group formation became a first step of the strategy agreed during the Marombuk. Farmers agreed to organize themselves in a group to catalyze the implementation of the program, with each member of the group representing their household. Farmer group formation was initiated in all villages at the end of March 2006 with the process complete in 2 months (see Table 1). The establishment of rubber nurseries was selected as the prior activity by all groups as a means to learn how to organize their group.

Group formation was not easy and a number of difficulties emerged during the process of initial group dynamics. Transparency in all activities was recognized by all FG members as key to solution of every problem and difficulty emerged in the group dynamic. Strong group dynamic occurred in all farmer groups in the first 6 months, some of the FGs re-organized, e.g. WEK1 merged their 2 FGs into 1 FG. After 6 months, FG in all villages become more established and continued to evolve. 
Table 1. First two-months process of the farmer group formation in Batang Toru area

\begin{tabular}{|c|c|}
\hline Time & Farmer Group Formation Process \\
\hline $0-2^{\text {nd }}$ week & $\begin{array}{l}\text { Socialization of the strategy agreed during the Marombuk in each focal village. } \\
\text { Village meetings held to initiate the farmer group formation. All villagers were } \\
\text { invited to join in the farmer group. }\end{array}$ \\
\hline $2^{\text {nd }}-4^{\text {th }}$ week & $\begin{array}{l}\text { Farmer Groups were formed based on the agreement during village meeting. Head } \\
\text { of the farmer group was elected during the group formation, and became } \\
\text { responsible in leading the members to develop and organize FG rules. ICRAF } \\
\text { played a role as facilitator in the group formation process. The following FGs } \\
\text { emerged: } \\
\text { 1. Sibulan-bulan: } 1 \text { farmer group (Anggiat Maju), } 27 \mathrm{HH} \\
\text { 2. Sitandiang: } 1 \text { farmer group (Suka Maju), } 23 \mathrm{HH} \\
\text { 3. WEK I: } 2 \text { farmer groups, (Martumbur and Satahi), @ } 26 \mathrm{HH} \\
\text { 4. Aek Nabara: } 1 \text { farmer group (Mekar Jaya), } 20 \mathrm{HH} \\
\text { 5. Hutagurgur: } 1 \text { farmer group (Satahi), } 20 \mathrm{HH}\end{array}$ \\
\hline $5^{\text {th }}-8^{\text {th }}$ week & $\begin{array}{l}\text { Rubber nursery construction became the FG's first focus activity. Operational } \\
\text { procedures to construct and maintain the nursery were developed autonomously by } \\
\text { each farmer group (with the ICRAF/Winrock team providing guidance and input } \\
\text { when requested). In the first } 3 \text { months, farmers conducted weekly "gotong royong" } \\
\text { in their nursery as nucleus for group meetings, and they apply sanctions to member } \\
\text { who didn't attend the "gotong royong" such as: } \\
\text { - Sitandiang - if a member fails to provide gotong royong to activities } 2 \text { times s/he } \\
\text { will be removed from the group; } \\
\text { - Sibulan-bulan - if a member fails to provide gotong royong to an activity s/he } \\
\text { must pay Rp 30,000 to the group. } \\
\text { - WEK I, Hutagurgur and Aek Nabara operational procedures were under } \\
\text { development. }\end{array}$ \\
\hline
\end{tabular}

After 1 year, three FGs were registered at the subdistrict government (see Table 2.). Being registered at subdistrict government is an advantage, because it gives FGs access some important information or supports (e.g. financial, facilitation) from the local government. Of the 5 FGs, only those in Sibulan-bulan and Hutagurgur village had active participation by women farmers. In the other 3 villages (Aek Nabara, Sitandiang and WEK1), women did not participate actively in the FG activities due to the strong local culture which does not allow men and women to work in mixed groups. 
Table 2. Farmer groups status in Batang Toru area after one year formation process

\begin{tabular}{|c|c|c|c|c|}
\hline $\begin{array}{c}\text { Focused } \\
\text { Village } \\
\end{array}$ & FG Name & $\begin{array}{c}\text { Members } \\
(\mathrm{HH})\end{array}$ & Status & Note \\
\hline Sibulan-bulan & $\begin{array}{l}\text { Anggiat } \\
\text { Maju }\end{array}$ & 23 & $\begin{array}{l}\text { Registered at } \\
\text { sub district } \\
\text { government }\end{array}$ & $\begin{array}{l}\text { Ca. 70\% of the active members in } \\
\text { this FG were women (some being } \\
\text { widows). } \\
\text { FG regulation is clear, well- } \\
\text { documented, and implemented } \\
\text { consistently. } \\
\text { Weekly meetings were conducted } \\
\text { consistently until the end of the } \\
\text { program. }\end{array}$ \\
\hline Sitandiang & Suka Maju & 23 & $\begin{array}{l}\text { On-going } \\
\text { process in } \\
\text { being } \\
\text { registered at } \\
\text { sub district } \\
\text { government }\end{array}$ & $\begin{array}{l}\text { Ca. } 5 \% \text { of the active members in this } \\
\text { FG are women. } \\
\text { FG regulation is not clear and not } \\
\text { documented } \\
\text { Bi-weekly meetings were conducted } \\
\text { in the first } 6 \text { months. After } 6 \text { months, } \\
\text { there were only occasional meetings } \\
\text { conducted. }\end{array}$ \\
\hline WEK1 & $\begin{array}{l}\text { Martumbur/ } \\
\text { Satahi }\end{array}$ & 34 & $\begin{array}{l}\text { Registered at } \\
\text { sub district } \\
\text { government }\end{array}$ & $\begin{array}{l}\text { No women active in this FG. } \\
\text { FG regulation is clear and well- } \\
\text { documented, but not consistently } \\
\text { implemented. } \\
\text { Monthly meetings were conducted } \\
\text { consistently until the end of the } \\
\text { program. }\end{array}$ \\
\hline Aek Nabara & Mekar Jaya & 13 & $\begin{array}{l}\text { On-going } \\
\text { process in } \\
\text { being } \\
\text { registered at } \\
\text { sub district } \\
\text { government }\end{array}$ & $\begin{array}{l}\text { Ca. } 5 \% \text { of the active members in this } \\
\text { FG are women. } \\
\text { FG regulation is not clear and not } \\
\text { documented. } \\
\text { No clear schedule for the FG } \\
\text { meeting. Meetings were conducted if } \\
\text { necessary. }\end{array}$ \\
\hline Hutagurgur & Satahi & 21 & $\begin{array}{l}\text { Registered at } \\
\text { sub district } \\
\text { government }\end{array}$ & $\begin{array}{l}\text { Ca. } 30 \% \text { of the active members in } \\
\text { this FG are women. } \\
\text { FG regulation is not clear and not } \\
\text { documented } \\
\text { Monthly meetings were conducted } \\
\text { but not consistently. Meetings were } \\
\text { conducted if necessary. }\end{array}$ \\
\hline
\end{tabular}

\section{Training Series}

The training series was aimed at building farmers capacity to transform their agroforest garden into more productive, market oriented and environmentally friendly systems. The trainings were conducted with the subjects as agreed in the Marombuk. Training series were divided into 3 major categories: (i) Agricultural techniques, (ii) Marketing aspects of agroforest products, (iii) Linkage of livelihood-conservation. 


\section{Building capacity on agricultural technique}

In the building community capacity on agricultural techniques, low productivity of agroforest garden was identified as one of the problems that need to be improved through training series. Based on farmers' opinion during Marombuk, the causes of low productivity were:

(i) Irregular spacing

(ii) Low intensity of maintenance

(iii) Less effective and less efficient rubber tapping technique

(iv) Low level of knowledge on pest and disease handling

(v) Low quality of tree germplasm (seedlings).

\section{Focus Agricultural Commodities}

Based on community's priorities and needs that were identified in Marombuk and a preliminary social economic survey in the area, 3 major agricultural commodities were selected as focused subject training activities in the area:

1. Rubber (Hevea brasiliensis)

Rubber was selected because it accounts for about 70\% of farmer's livelihood; it has been significant smallholder crop since before year 1900 .

\section{Cacao (Theobroma cacao)}

Cacao is a relatively recent introduction in the area, with the oldest cacao garden established in 1980-ies. The high price of cacao (IDR 9000-11000/kg) has tempted farmers to plant more cacao in their garden.

3. Aren (Arenga pinnata)

Aren is a palm tree that grows naturally and is tapped by the farmers for sugar production.

In Indonesia, palm sugar is made from sap tapped from the flower stalks of either the coconut (Cocos nucifera) or the sugar palm (aren).

Of those 3 commodities, rubber became the main focus in the training series and facilitation process since it is the main commodity for most farmers. Besides focusing on those 3 commodities, we are also explored the potential of livestock as a livelihood option.

\section{Target participants}

Training series were open to all villagers at the 5 focal sites, with an option to include participants from neighboring villages who are keen in gaining knowledge from the training. Farmer groups received more intense capacity building facilitation as the FG members (male and female) were expected to be the agricultural agent to transfer the knowledge they have gained from the training. Extension officers were also invited to join the training, in order to increase their capacity in serving the community needs.

\section{Methods and Facilitators}

The training series combined class sessions and field practice. A range of methods was used in the training series, in a flexible response to the way the situation evolved. ICRAF staff were the main facilitators and were assisted by the experts (local experts/farmers, lecturer, 
scientist from research institute, specialist volunteers from Winrock International) of specific subjects in the training series.

\section{Subjects of the training series}

Based on the problem identified in Marombuk, subjects prioritized for the training series within the 1.5 years timeframe were:
A. Rubber, including: (i) Clonal rubber seedlings production, (ii) Agroforest garden management, (iii) Pest and disease handling, (iv) Tapping management
B. Cacao agroforest management
C. Sugar palm harvest and post harvest handling
D. Small ruminant livestock as livelihood options

\section{Training Series:}

\section{A. Rubber (Hevea brasiliensis)}

More than half of the latex production in Indonesia originates from smallholder rubber gardens where rubber grows in a mixed tree species garden with various garden management styles. These mixed systems are also known as agroforest garden. Having diverse tree species in their agroforest garden has been perceived by the farmers as an advantage for their livelihood sustainability and also providing intangible environmental services. Per unit area the production of any single species is lower in an agroforest setting than in a monoculture system, so there are tradeoffs between the products and services that can be derived from a rubber-based agroforest.

Rubber agroforests cover ca. $70 \%$ of the Batang Toru area with low latex production (less than $500 \mathrm{~kg} / \mathrm{ha} / \mathrm{year})$. Problems with latex production are not only in the quantity but also quality of local processing. Latex quantity is mainly controlled by the farmers and the natural capital condition, while the latex quality is mainly driven by the traders and the market incentives. Hence, in order to enhance the latex productivity in the area we need to modify the quality of those 4 aspects (farmers, natural capital, traders and markets). Low latex quality and quantity in Batang Toru area at the farmers level was identified because: (i) low rubber density (trees/ha) in the garden (50-150 trees/ha), (ii) unorganized tapping management, (iii) less maintenance, and (iv) farmers still using the wilding seedlings without selection for latex production properties. Thus, to improve latex production in Batang Toru area, at farmers level it is necessary to conduct series of training to improve farmers' knowledge on 3 aspects:

\section{Planting material (germplasm quality)}

A series of trainings was conducted to enhance rubber tree germplasm quality in Batang Toru area, as planting material selection is the fundamental activity in domesticating rubber tree for source of sustainable livelihood. Farmers' knowledge on producing good quality of rubber planting material was improved through training series on:

(i) Rubber nursery construction (rootstock and budwood ('entres' or scions) garden)

(ii) Rubber grafting techniques 


\section{Garden management}

Most of the rubber agroforest in Batang Toru area was established before Indonesia's independence and has bee been inherited by the current farmers, with extensive management and low intensity maintenance applied to the garden. Trainings in garden management aimed at knowledge of tree spacing, pest and disease handling, and tree maintenance. Knowledge of marketing opportunities influenced farmers' decision in selecting trees that can be maintained in their agroforest garden.

\section{Latex harvesting management}

Generally, farmers were not aware that after rubber trees reached tap-able size, the sustainability of their agroforest' latex production will be affected mainly by the rubber harvesting technique and management. Rubber trees will stop producing latex if it is overexploited, and may die shortly after. Therefore it is important to conduct training in improving farmers' understanding on the urgency of tapping management that maintains tree vigor while producing latex.

Details of the rubber training series on clonal rubber seedlings production, agroforest garden management, pest and disease handling, and tapping techniques are described in the Appendix 1 through 4, respectively.

\section{B. Cacao (Theobroma cacao) agroforest management}

Cacao was introduced to Sumatra in the $18^{\text {th }}$ century by the Dutch, and began to boom in Batang Toru area in 1980-ies. At that time, farmers planted cacao in their mixed garden mostly because of its good market potential (high price). However, apparently, it is evident that the cacao smallholder farmers in North Sumatera, Indonesia, have less information on the cacao domestication aspects, leaving them to trial and error kind of learning, which leaded to low maintenance intensity that imply to the low cacao productivity (quality and quantity) in the area.

Cacao domestication and harvesting method in Batang Toru region is not different from that in other tropical areas. Farmers are cultivating cacao by collecting seeds from their best trees, germinate them on plastic bags and put them under shaded area near their plantation. Few months later the new plants were taken to the fields, and planted under the shade of older trees (natural forest or planted forest to the purpose of it). In Batang Toru area the planting distance is primarily $3 \mathrm{~m} \times 3 \mathrm{~m}$. Other farmers try to plant cacao in more dense distance without understanding the principles of competition among plants and the need for pruning later on the road. Apparently, most of the seedling in the garden started to show signs of lacking maintenance (pruning and pest and disease handling). Farmers still practicing less maintenance for their cacao trees without fertilizers and pesticides.

Hence, a smallholder cacao specialist from Winrock International's Farmer-to-Farmer program (Dr. Juan Guzman) was invited to assist farmers and traders through informal discussion and training. The objective of the training is to enhance farmers' knowledge in cacao garden management, post-harvest handling, and market linkage that could increase the cacao productivity in the area. The training was focused in 3 villages that have the highest cacao potential compare to the other 2 project villages: 
(i) Hutagurgur - 26 April 2007 (5 farmers (1 female and 4 males) 1 trader),

(ii) WEK1 - 27 April 2007 (10 farmers, 2 local traders),

(iii) Sibulan-bulan - 29-30 April 2007 (20 farmers (13 females and 7 males), 1 sub district trader).

The training including: (i) visiting cacao fields, (ii) discussion on cacao domestication in the field and in class, (ii) discussion on cacao marketing (local market, trading habits) with trader in the weekly market, (iv) practical training on cacao pruning techniques. During the training, farmers showed enthusiasm for learning more about cacao domestication and marketing. In those 3 villages, same questions were asked both by the farmers and the traders (Table 3.).

Table 3. Questions asked by the farmers and traders in the cacao training in Batang Toru area

\begin{tabular}{|l|l|}
\hline \multicolumn{1}{|c|}{ Farmers level } & \multicolumn{1}{|c|}{ Middleman/trader at subdistrict level } \\
\hline $\begin{array}{l}\text { 1. What pesticide/fertilizers should be applied } \\
\text { to the cacao trees in order to gain good } \\
\text { production? }\end{array}$ & 1. How to get higher prices from the exporter? \\
\hline 2. How to produce superior cacao seedlings? & 2. Where to sell cacao with the higher prices? \\
\hline 3. How should pruning be conducted with & $\begin{array}{l}\text { 3. What factors that can influence the stability of } \\
\text { cacao beans price? }\end{array}$ \\
\hline 4. Is it ok to grow cacao tree in swampy area? & \\
\hline
\end{tabular}

Based on the situation evolving in the field and also from the discussion during the training session, constraints in enhancing the cacao productivity in the area included:

1. Post harvest handling aspects:

(i) Cacao seeds fermentation method is not preferable by the farmers because they receive the same price whether the cacao fermented or not. Fermenting cacao seeds will enhance the cacao flavor and the quality of cacao seeds. Hence, fermented cacao seeds should receive a higher price.

(ii) The cacao seeds drying methods currently used by the farmers are ineffective for the daily high rainfall conditions of Batang Toru area. Drying the seeds on plastics will make the drying process longer. It is better to dry the seeds on cement areas.

2. Marketing aspects:

(i) Cacao market in the area is still undeveloped due to the various level of traders involved and resulting lack of market transparency regarding product specifications, prices, etc.

(ii) No cacao farmer or trader association in the area.

3. Domestication aspects:

(i) Farmers still do not use the certified seeds for cacao domestication.

(ii) Pruning and other maintenance practices receive little attention from farmers. 
Constraints to cacao production can be eased by implementing the recommendations below:

1. Improving cacao quality through the introduction of cacao seeds fermenting process.

2. A detailed cacao market study/data collection is required to stimulate the production of high quality cacao (study of: market flows; prices at different points in the market chain, seeds quality grading at traders level).

3. Build communication network between producers (farmers), traders and the Indonesian Cacao Research Institute.

4. Exploring cacao fair-trade market initiatives or organic certification for cacao products (cacao powder, chocolate syrup, cacao butter). This could hold high potential, as the smallholder farmers in Batang Toru area grow their cacao tree under eco-friendly, sustainable practices (under shade, forest-like garden).

5. Initiating the formation of cacao farmers association or cacao traders association and increasing farmers' recognition of the advantages of operating in a group (better access to production technology, post harvest technology and marketing information).

\section{Sugar palm (Arenga pinnata) harvest and post harvest handling}

In North Sumatra, aren sugar palm (Arenga pinnata) trees are maintained by the farmers for two main products: $90 \%$ for traditional beverage (tuak) and only $10 \%$ for sugar. Farmers in Moslem area prefer to process the nira (aren sap) for sugar, while those in Christian areas prefer to process the nira for tuak. The average production of sugar palm in North Sumatra is 2708 ton from 4400 ha aren agroforests that are concentrated in 2 districts, i.e. Karo and South Tapanuli. Sipirok and Marancar are known as the most productive subdistricts for aren sugar in the South Tapanuli district. Two of the project focused villages are located in that area, i.e. Sitandiang in Sipirok subdistrict and Aek Nabara in Marancar subdistrict. The daily income of those 2 villages is derived $80 \%$ from aren and $20 \%$ from rubber.

Farmers in Batang Toru tapped aren trees that occur in their garden by the standard method used throughout Indonesia and recognized by sugar palm specialists as the appropriate method aren (Mujahidin et al, 2003). Generally, aren trees that occur in farmer's garden are established through natural regeneration. Civets are known as a natural agent of aren tree regeneration and distribution. In these natural systems there are only 10-15 aren trees per farmer garden (averaging 0.5 to $1 \mathrm{ha}$ ). Other trees - commonly cinnamon, rubber, fruit trees are also found at irregular spacing in 'aren gardens'.

The productivity of these mixed aren garden is approximately 1 ton aren sugar/ha/year and ca. 10,000 liter of tuak/ha/year. Those production numbers are normal for mixed gardens. The quality of the sugar can be improved to obtain a better price. Hence, in improving the sugar palm quality, there are 2 major aspects that need to be modified, the harvesting and post harvest processing (at the farmer level), and the market linkage (at the trader level). Modifying the domestication aspects is also important in maintaining the sustainability of aren trees and gardens.

Improving farmers' knowledge on the harvesting and post-harvest handling aspects was identified as the first priority to enhance farmer aren productivity in the Batang Toru area. A one-day training, with informal discussion and shared experience, was conducted in the two villages where aren is a priority crop (Aek Nabara on 9 April 2007 and Sitandiang/Bulu 
Mario on 10 April 2007). The objective of the training were: (i) increasing farmer knowledge in improving their post harvesting handling by share knowledge of sugar palm production in other area (West Sumatra Province), and (ii) identifying other main problems to maintain the sustainability of sugar palm production in the area as source for local people livelihood. A lecturer from Andalas University, West Sumatra (Dr. Gunarif) was invited as key speaker in the discussion session. Informal discussions were conducted in village coffee shops, sugar palm gardens, and at the traditional sugar palm processing places. Farmer participants in each of the village were 10 in Aek Nabara, 4 in Sitandiang ( 1 female and 3 males) and 7 in Bulu Mario village ( 1 female and 6 males). Training groups also visiting 3 aren processing sites (1 in Aek Nabara and 2 in Sitandiang).

Key questions that were raised by the farmers during the informal discussion were:

1. How to enhance the aren sugar palm production?

2. How to produce solid palm sugar (which will not melt easily)?

3. What material that can be used to conserve the nira?

4. How to further domesticate aren trees? Is there any superior aren germplasm available?

5. What are the characteristics of the superior aren trees (in regards to nira productivity)?

6. How best to produce palm sugar? And what is the market potential aren sugar?

Key problems to aren productivity were identified as those affecting harvest and post harvest handling (see Appendix 5):

(i) Little attention is given to using cleaning processing equipment (particularly the sanitation of the collection tube), with implications for:

a. Degrading the sugar content in nira which lowers the quantity of aren sugar palm produced per liter. In the Batang Toru area $3 \mathrm{~kg}$ sugar palm are produced from 1 kaleng (i.e. 20 liters) nira; normally 1 kaleng produces 4 kg sugar palm.

b. Nira crust formed in the insufficiently cleaned tubes reacts with the new nira liquid and forms acid substances which degrades the sugar content in nira resulting in a soft ('easily melted') consistency of the palm sugar produced.

(ii) Size of the palm sugar bundle. Currently the farmers produced palm sugar in $5-20 \mathrm{~kg}$ units. Standard market units are 0.5 to $1 \mathrm{~kg}$. Farmers could gain an additional Rp 500/kg if they produced standard market units. Farmers consider that the additional income for producing small-sized bundle is not worth it, but they have not tested the option.

(iii) Fuel wood availability can become a major problem in the area. Approximately 1-2 cubic meter of wood per week per farmer is needed to cook nira for sugar palm production.

The following recommendations were provided to address these problems:

(i) Equipment cleanliness needs to receive high attention from the farmers, particularly the collecting tubes, because less sanitized equipment will cause low sugar palm quality (easily melted and low sugar content).

(ii) Techniques need to be adopted: 
a. At the preparation stage before the flower is tapped, the male flower need to be beaten diagonally. In West Sumatra, this technique is proven to be more effective than beating the male flower horizontally.

b. Trees with male flower that emerge beneath the female flowers will produce more nira that male flower that emerge above the female flowers. Therefore, male flowers that emerge above the female flowers are not recommended to be tapped.

c. Additive materials containing oil, e.g. candlenut, coconut milk, palm oil, need to be added to the simmering nira during the cooking process for optimal results.

d. Scum that usually occurs during the nira cooking process need to be removed, because it can cause a dark color of the sugar and also can caused the sugar to easily melt.

(iii) Alternative solution to the fuel wood problem:

A lack of fuelwood has hampered sugar palm production in some area in Indonesia. Therefore, encouraging farmers to plant (or maintain) trees that are good for fuelwood and can yield other products that can add more income to the farmer, e.g. cinnamon.

(iv) Marketing aspects:

Farmers will receive higher price if they produce small size sugar palm bundle (0.5 to 1 $\mathrm{kg} /$ bundle) than big size sugar palm bundle (5-20kg/bundle) because there will be no cost for re-processing the sugar palm from big size to the small size that are preferable by the consumers. Farmers said that if they received at least additional 30\% incentive (instead of the current $10 \%$ ) from the market, they will produce small size bundle. Therefore, improving the market linkage will enhance the price received by the farmers.

(v) Additional farmer trainings that should be conducted:

a. Aren sugar palm domestication aspects (recommended trainer: Mujahidin from Kebun Raya Bogor)

b. Palm sugar process and its market potential (recommended trainer: Gunarif from Andalas University)

\section{Small Ruminant Livestock Potential as Livelihood options}

Diversifying livelihoods is important in sustaining the source of farmers' cash income. Currently, farmer in Batang Toru area income is ca. $75 \%$ from marketing agricultural products (rubber, sugar palm, etc) from their mixed-tree garden (agroforest) and the other $25 \%$ from rice (quarterly production) and fruits (annual production). Livestock is not yet a significant livelihood options for the community in Batang Toru area, although farmers recognize the potential of livestock (goats, cows) production. Capital (money) is the main limitation for household livestock production.

Approximately $10 \%$ of Batang Toru farmers own small ruminant livestock, mostly goats (in the Moslem community) and pigs (in the Christian community). These farmers generally have more capital compare to other farmers within the village. According to farmers, beside capital, reasons for the low livestock production in the area are: (i) low market potential, (ii) less knowledge in nursing the livestock that imply to the less motivation from the farmers. 
A one-day training seminar leaded by the Small Ruminant Livestock Specialist, Nancy Morey, volunteer from Winrock International's Farmer-to-Farmer Program was conducted in two focal villages i.e. Sibulan-bulan (26 Nov 2006) and WEK 1 (28 Nov 2006). ICRAF staffs were the facilitators in the training. The objectives of the training were: (i) to build farmer awareness of the potential of livestock production as an alternative livelihood, (ii) to provide recommendations on how to improve smallholder livestock production in Batang Toru area. Number of participants in the training: Sibulan-bulan (33 participants, 25 females and 8 males) and WEK1 (17 male participants).

Currently in those 2 villages, there is only $10 \%$ of households raise goats, while nearly all households have some chickens. The training seminars provided general knowledge and strategies to enhance local people awareness/technical capacity to raise goats/livestock as a livelihood alternative for additional income. This is of great interest to communities.

Based on the issues discussed during the training key options to increase the livestock production in the Batang Toru area, are:

1. Disease, health and sanitation problems:

(a) Improve the sanitation and health problem through follow up activities with HEIFER Indonesia.

(b) Explore traditional medicine for treating diseases.

2. Local community self exploration to improve their livestock: Develop local initiation among farmer to prioritize and solve livestock production problems.

3. Detail marketing study on livestock is required. Currently, most of the villagers sale their livestock only during Islamic fest (Idul Adha), the price varies between IDR 350,000 for Lamb and IDR 700-800,000 for adult goat or sheep.

4. Synergizing villagers' need with the Government Livestock program on integrating the animal husbandry and farming system in regard to increase the community's income.

\section{Building community capacity on agroforest marketing aspects}

Communities in Batang Toru are mainly dependent on agriculture for their livelihood. Thus, improvements in garden management and product marketing would lead to livelihood enhancement. Generally, farmers will plant agricultural commodity based on their perception of market demand, i.e. species with high economical value. Thus crop selection is essential if farmers want to gain optimum profit from marketing their agroforest products. Beside species selection, post harvest handling activities will also influence the quality of the product where high quality products will link to the markets which offered best price.

Training to enhance Batang Toru community capacity in product marketing was conducted. Identification of marketing problems was conducted as the first step to build the farmers capacity. A marketing study was conducted using Rapid Market Approach (RMA), commodity and institutional approach. The commodity approach focuses on what is done to the product after it leaves the original point of production. The approach follows the commodity along the path from producer to consumer and is concerned with how the commodity could be handled more efficiently. The institutional approach focuses on how 
farmer/market agents behave, make decision, interact among others and influence the market channel performance.

Based on the field observation in the Batang Toru area, more than $90 \%$ of farmers sold their agroforest product weekly to the local market. Farmers use local markets because they have low accessibility to other market (distance to other market is too far, high transportation cost, bad roads/infrastructure). In some cases, farmers prefer to sold the products to the local traders (at village level), this can be a disadvantage for the farmer when there is only 1 buyer/trader in the village then opportunity for monopoly will be bigger. With monopoly, farmers will receive lower price. Marketing channel that applied in Batang Toru area for rubber, coffee, cacao and salak (snakefruit) are described below:

- Rubber

Farmers $\rightarrow$ local traders (village level) $\rightarrow$ traders at the subdistrict level $\rightarrow$ processing factory

\section{- Coffee and Cacao}

Farmers $\rightarrow$ local traders (village level) $\rightarrow$ traders at the subdistrict level $\rightarrow$ exporter (from Lampung, Medan, Padang)

\section{- Salak}

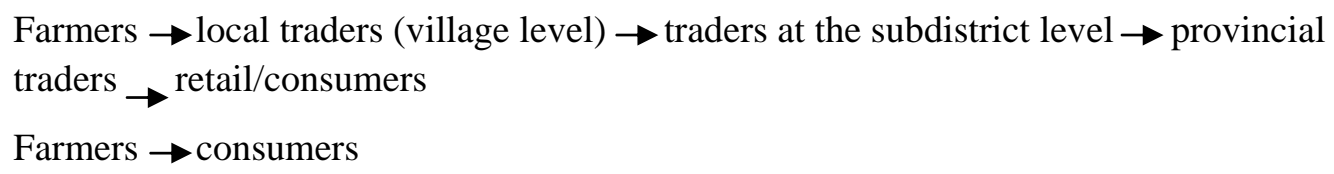

Agricultural marketing issues and situation in Batang Toru are common for smallholder farmers in other parts of Indonesia and throughout the tropics. Key obstacles are: (i) low and inconsistent quantity, (ii) low and unequal quality, (iii) limited access to market (global price) information, (iv) high transportation cost, (v) farmers sold the product individually, not yet through group/association.

Obstacles that were identified through RMA, was used as basic issues in May 25 - 27, 2006 in Sitandiang, Sibulan-bulan and Aek Nabara (North Sumatera), with the focus on enhance smallholder knowledge on agriculture/agroforestry marketing issues and its practices. Seventy eight farmers, 2 market agents and other stakeholders (from ICRAF, Conservation International, Local government) engaged in the training. The objective of the mini training was to increase farmers' awareness and understanding of market linkages and functions through providing technical knowledge, market information and identify the marketing problems that could address by farmers.

Formal and informal discussions held during the training used a participatory approach. Workshop sessions sought to: i) share knowledge on basic concept of markets and its system; ii) discussion session to provide opportunity for farmers and market agents to share their experience and problems related to the smallholder product market segment; iii) learning from successful story of farmers linked with market from other site/project; iv) develop follow-up plans to help farmer groups enhance the quality of their agroforestry products and market linkages, and v) enhance farmers perception on the correlation of improve tree garden management and marketing of farmers produce with conservation. 
The title of the mini-training was Linking Farmers to Market. ICRAF smallholder marketing specialist shared ICRAF knowledge and experience regarding product marketing at the farm level. The marketing of rubber and fruit products were the issues that catch farmers' main attention. As this kind of training was new for the Batang Toru farmers, most of the farmers were excited in participating the training. Discussions on local problems in marketing agricultural products were very productive, yielding excellent responses from the farmers. The dependency of local farmer on traders in the market chain was identified as the main problem in all five villages. The ICRAF Team helped farmer participants produced draft follow-up plans on how to enhance marketing of their agricultural products.

During the training, there was session where community specialist from CI delivered some ideas on how to link the habitat orangutan conservation with livelihood strategy through marketing aspect of agricultural products. The main idea was by paying more attention on marketing aspect of agricultural products, the farmers' livelihood will be enhanced by doing more intensive and better garden management in order to produce agricultural product with better quality and quantity, by doing so farmers do not need to go to the forest for shifting cultivation activities. There was no direct response during the presentation of marketinglivelihood-conservation. Farmers clear considered this issue and some farmer-to-farmer discussion occurred during breaks and after the mini training events. Farmers need additional time to reflect on this important issue.

A second marketing training to build farmer' agricultural marketing awareness was conducted from 25-31 August 2006. The purpose of the event was to follow-up on key issues from the previous marketing training activity. A smallholder agricultural production and marketing specialist volunteer from Winrock's Farmer-to-Farmer Program, Greg Fonsah, who previously assisted the ICRAF Nanggung program with horticultural production and marketing issues, participated in the marketing survey activity. Based on the importance and the quantity provide by the farmer per month, marketing issue for Batang Toru program is focused into 3 commodities, namely: rubber, cacao and sugar palm.

\section{Recommendation}

The following recommendations emerged from the second marketing training activity:

1. Rubber and cacao should be priority species for which to develop better farmerprivate sector linkages.

2. Farmer groups who are located closely to market (have good access to market) are encouraged to identify the specific requirement of product from (regional traders) district or province level to identify the opportunities to link with market.

3. Improvement on the garden planning (species selection, source of germplasm for planting material) and maintenance (weeding, fertilizing), and post harvest handling are important aspects that should be notice at farmers level.

4. Farmers need supports from stakeholders (government, NGO, private sector) to organize themselves in marketing group with focused on one or two main product that holds high market demand.

5. Cooperation that mutually benefiting farmers and traders need to be build. 


\section{Building community capacity on awareness of linkage between livelihood and conservation}

Developing convincing linkages between nature conservation and livelihood enhancement, via activities in the village and via recommendations from other stakeholders, was one of the main objectives of the Batang Toru project. As part of the work done to support this objective, the concept of community-level "Conservation-Livelihood Agreements" or "Kesepakatan Konservasi-Penghidupan” (KKP) was socialized and developed. The main idea behind the KKP is that through participatory, equitable, multi-stakeholder involvement the KKP document will be drawn up to articulate a community-level strategy that ensures conservation of critical orangutan forest habitat and enhancement of local livelihoods; the KKP document includes strategic as well as regulatory, monitoring, and enforcement protocols. Basically the KKP is to serve as the primary document supporting the development of a real conservation-livelihood linkage in the project villages. The main functions of the Conservation-Livelihood Agreement (KKP) are to:

a) Provide specific guidelines (strategy, local regulatory framework, monitoring, enforcement, etc.) on the management of and conservation of natural resources and forest ecosystem in the area. Including strategies for negotiation on the conservation-livelihood issues.

b) Act as "community education media" which supports the fair, equitable, and sustainable management of natural resources and the forest ecosystem

c) Support transparency and open sharing of information amongst all parties

d) Support and provide historical evidence of the community rights to manage and conserve their natural resources and forest

e) Officially recognize the community tradition of and responsibility to sustainable manage their natural resources

Community conservation-livelihood agreements in Batang Toru project were developed in three villages of five focal villages. The approach used provided effective use of resources (time, energy, monetary, etc) and assured success by focusing where communities and their conditions are supportive. Village selection was based on the criteria of existing forests and a local commitment to conservation. Analysis from BPS 2003 data and satellite imagery indicates that there is only small patch of the remaining forest in Hutagurgur and WEK 1 villages, thus these two villages were considered lower priorities for facilitating and development of conservation-livelihood agreements.

At the initial stage of socializing the KKP (in May 2006), most villagers in the project area were becoming aware of the issue, especially in the villages where accessible land is scarce. For instance, villagers from Aek Nabara and WEK 1 have paid special attention to discussion on the conservation issue, because the local people have limited access to the forests, as the forests status adjacent to WEK1 village is unclear and those around Aek Nabara are protected forests. The concept of agreement on the linkage between conservation and livelihood were developed gently, based on the issue as drawn in Figure 3. Discussion and consultation with key stakeholders (villagers, sub-district officials, district officials, and forestry officer) were maintained during the process. 


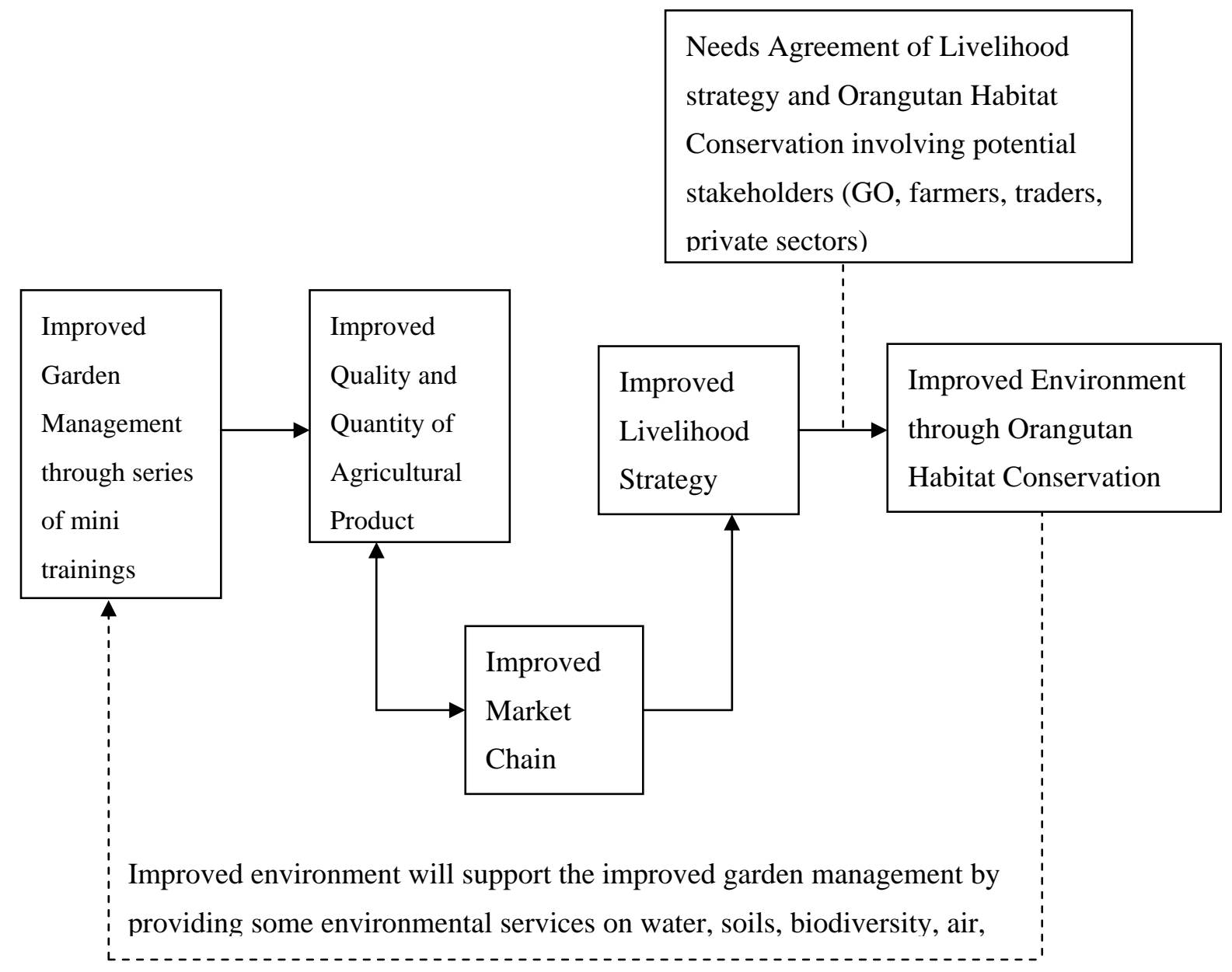

Figure 3. Linkages between livelihood and conservation in the context of nature resources

management (Solid arrows indicate direct linkages, dashed arrows indicate indirect linkages).

The first conservation-livelihood linkage meeting was held in mid-July 2006 to socialize the conservation-livelihood concept and to initiate the formation of the KKP (Kesepakatan Konservasi dan Penghidupan) working group at village level. A Conservation and Livelihood Enhancement Specialist, Melissa Abdo, volunteer from Winrock International's Farmer-toFarmer Program was invited to the meeting to catalyze the KKP socialization process. Meetings were held in all three selected villages: Sibulan-bulan, Sitandiang and Aek Nabara. Participants in the KKP meeting included representatives of the: kepala desa (village heads), ketua BPD (heads of BPD), FGs, adat (cultural) and religion organizations, youth organization, teachers, forest users and other community groups. All three communities agreed to proceed in developing the KKP by forming KKP working group (KKP-WG) before end of August 2006. The process for establishing working group was led by the village head and BPD (village representative board). ICRAF facilitated the working group in developing workplans in each village.

During the first KKP meeting efforts were made to identify the main problems/issues related to natural resource conservation and local livelihoods in each community. These problems/issues are vital considerations that affect the conservation-livelihood agreement development process. Key problems/issues vary between villages. For instance, Sibulan-bulan community would like to clarify their land use security and border demarcations with 
neighboring villages (particularly Sidua Bahal, but also other villages). While Sitandiang community was primarily interested to clarify the demarcation between village land and forest lands to prevent potential conflict with national government agencies. People in Aek Nabara want clarity regarding borders between village land and protected areas (Cagar Alam) in their KKP agreement.

The KKP working group formation process was successful in all communities. This can be seen from the selection of the KKP working group (KKP-WG) members (i.e. representatives from various group in the village were urged as member of the KKP-WG). After KKP-WG was formed, the working group developed a working plan for their routine monthly meeting. The monthly meeting was routinely conducted during a 6-month period, during the meetings planned agreement items concerning to conservation and livelihoods were discussed. Unfortunately after 6 months, the member of KKP-WG per village began to question the urgency in developing the KKP. They concluded that building same vision and understanding about the KKP concept among the KKP-WP members need to be developed first before they deliberated the urgent issues in the livelihood-conservation linkage.

After 6 months, the KKP process was stagnant in Aek Nabara and Sitandiang due to the community couldn't see the KKP as their prior. More importantly, rumors regarding the secret development of the Batang Toru area as a national park killed communities' previous enthusiasm for the development of KKPs. Communities rightfully questioned the government and other stakeholders' commitment to an equitable and transparent process. Only in Sibulanbulan village did the KKP process continue through the end of the project; and even this was not smooth. Hence, at was decided to focus KKP development with the Sibulan-bulan community.

At the end of the Batang Toru project, a meeting with Sibulan-bulan was held to evaluate the KKP process and develop follow up plans. The main issue raised by stakeholders regarded whether or not they really felt they needed the KKP. This issue was especially prevalent within the KKP Working Group. Most of the members seemed to agree that it was something that would benefit the community and was necessary; however some of the members remain undecided. Still a smaller group (2 stakeholders) felt that there was no need for a KKP strategy and agreement; they felt it would be best to just rapidly impose/install Village Laws (Peraturan Desa) rather than first develop a strategy to inform any future creation of Village Laws. Hopefully, these issues can be overcome and resolved so that what seemed to be the wishes of the majority of the members of the Working Group - movement towards KKPs may be realized. However, through the end of the project no signed KKP documents were produced. The process successful enhanced local community awareness regarding conservation-livelihood issues.

With regards to key KKP issues raised by stakeholders, by far the most frequently mentioned issue was the importance of mixed agroforests and "natural” forest to their livelihoods, which they did not want to be "cut off" from when the KKP is developed. There is still a relatively high level of concern and tension amongst local stakeholders when the topic of conservation of these areas comes up, as “conservation” may be interpreted in many different ways. That must be considered in tandem with the fact that KKP working groups and Batang Toru communities in general all wished to conserve natural forests surrounding their villages and the biodiversity within them. They seemed to be clearly in favor of conservation. Importantly, 
they gave their reasons for wanting to conserve these areas as being related to serving both their livelihoods and in order to serve nature and biodiversity conservation goals. Again, they felt conservation could include "responsible," sustainable, extractive uses upon which they depend for their livelihoods. The communities' fear of conservation is only strengthened by the 'secret' steps taken by some stakeholders to develop a national park without including the concerns or input from local communities.

\section{Lessons learned}

Process in developing the KKP as a negotiation tool to link livelihood with conservation has enhanced local people awareness for issues related to those 2 aspects in the perspectives of different stakeholders who participate in the process. A key lesson learned from the KKP experience is that any village-level community agreements, rules, or laws should be inclusive, participatory, and transparent. Generally, such a process typically takes a lengthy amount of time in order for it to be done properly. Multiple stakeholders in the community should be involved in order to reduce the likelihood of future conflicts, and increase the likelihood that the agreement/rules will be heeded and effective in the community. 


\section{Conclusion/recommendations}

Farmers are very appreciative of and greatly benefited from the technical support provided by ICRAF and Winrock over the year and a half project period. Of the activities conducted, those related to rubber management and production had the greatest impact. The support has enabled farmers to greatly enhance their technical knowledge and capacity specifically:

a) Training series has increased farmers knowledge in managing their agroforest garden and increase their awareness on agroforest systems. Farmers also learned that by applying the knowledge they will be able to increase productivity of their rubber, cacao, and sugar palm agroforests systems by $10-15 \%$. On livestock issue, approximately 35 households have adopted recommendations regarding minimum level of goat management, which are yielding one additional buck annually. Income projections indicate additional income of US\$85/household/year.

b) Among the training series implemented, training related to the production of clonal rubber was considered the most important by most farmers. Farmers have learned the value of high value germplasm from the rubber nursery demonstration plots supported through the project. Most of the farmer groups with rubber nurseries have been able to sell approximately 2,000 high-quality clonal rubber seedlings to local farmers, government agencies and other customers. With the nursery materials supplied through the project, each farmer group earned an income of roughly Rp 4,000,000 or US $\$ 444$ (2,000 seedlings x @Rp 2,000).

c) 3 Farmer Groups have been registered to Forestry Department at the subdistrict level. The registered status provides Farmer Group with access to local government sponsored capacity building activities.

While their knowledge and capacity have improved, farmers agree they need additional technical and marketing assistance to maintain the current momentum in improving their agroforestry systems and strengthening community-based conservation. In particular farmers demand support from local government through local extension services. Specifically farmers would like more intensive facilitation from the extension officer. Farmer groups in all five communities agree to continue their agroforestry and conservation activities, and volunteer to transfer their knowledge to other interested individuals and communities. They hope to expand their information network with other farmers, NGOs, government agencies and the private sector to enhance their agroforestry and forest management capacity. 


\section{Appendix 1. Training series on Clonal Rubber Seedlings Production in Batang Toru area}

Enhancing tree germplasm quality is a key strategy to improve agroforest' productivity. In a rubber agroforest with latex as the main product, improving rubber tree germplasm quality is necessary to maintain latex production sustainability. The Indonesian Rubber Research Institute has improved rubber germplasm quality primarily through the production of clonal rubber types since 1980s., Unfortunately the information and material rarely reach farmers.

Research showed that rubber tree clones with improved genetic materials exhibit faster growth, hence the clonal rubber can be tapped 3-5 years more advance than wilding rubber. Wilding rubber trees quality is significantly varies in its individual growth and its latex productivity. By planting clonal rubber, it is expected that more consistent latex productivity will be obtained by the farmers with short time investment. Farmers are interested in planting the clonal rubber in their old garden in order to improve their agroforest productivity and profitability without having to expand the area of cultivation.

Current situation in Batang Toru area, only ca. 10\% of the farmers know and understand how to produce clonal rubber and most of them live near state rubber plantation, the other $90 \%$ of the farmers have limited knowledge on clonal rubber. Thus, farmers were keen to learn ho to produce clonal rubber themselves since clonal rubber material is expensive in Batang Toru. Hence, farmers requested some supports from ICRAF to assist them in learning more about clonal rubber, technique to produce it and technique to plant it in their agroforest garden. Thus, training series on enhancing rubber tree germplasm in Batang Toru area were conducted from April 2006 to May 2007 in 2 main steps:

1. Rubber nursery construction (April 2006-January 2007), divided into 2 sections:

1) Training series (combination of in class and field practice training) were given to enhance farmers' knowledge about rubber clonal material, technique to produce it and options of techniques to domesticate it in an agroforest garden. Training was conducted into 3 sub sections:

(1) Informal training facilitated by ICRAF staffs on the initial phase in constructing the rootstock rubber nursery.

(2) Intensive 3 days Training of Trainer (TOT) at Sungai Putih Rubber Research Institute for 3 farmers per village was conducted to produce potential farmers as local trainer that will be the key persons to maintain the sustainability of transfer knowledge flow from the resources to the farmers, particularly in constructing and maintaining rubber nursery during the program and after the program ended.

(3) Informal farmer to farmer training that was leaded by the potential farmers if necessary based on requests by the schedule decided by the farmer group members in the farmer group's routine meeting. 
2) Practice to construct 1 rubber nursery per village for 9 months was a learning-bydoing method to enhance farmers' skills in producing clonal rubber. Farmer Group was responsible in constructing and maintaining the rubber nursery in accordance with the rule made per Farmer Group. ICRAF provided the materials needed. Rubber nursery construction was conducted in 2 main areas:

(1) Rootstock rubber nursery construction

(2) A rootstock rubber nursery was constructed per village by the estimated capacity of 10000 seedlings (ca. 1/2-3/4 ha) in an area near the village and water, hence ICRAF distributed 20,000 rubber seeds of GT1 rubber clone per village. Nursery maintenance was managed by the Farmer Group, while ICRAF provided the fertilizers per 3 months and pesticides/fungicides if necessary.

(3) Entres (scions) garden construction

(4) Entres garden is expected to be used by the farmers as modal to produce clonal rubber in the future. Each village received 100 seedlings of PB260 rubber clone and 100 seedlings of BPM107 rubber clone that need to be planted in less than $1 / 2$ ha land near the village settlement to simplify its maintenance. The entres garden can be used to produce clonal rubber for 8-10 years, after 10 years entres garden need to be renewed. ICRAF provided the stumps and fertilizers in the first year.

2. Rubber grafting training (January-April 2007), was divided into 2 sections:

1) Training (combination of in class and field practice training) to enhance farmers' knowledge in grafting technique that can be applied not only to rubber but also to other tree species, e.g. cacao, also to introduce farmers to other potential vegetative propagation technique that may be applied for other tree species occurred in the agroforest garden. This 2-days training was conducted per village and open for public who keen in learning the vegetative propagation technique, particularly for rubber.

2) Practice in grafting rubber trees to produce clonal rubber from the farmer group rootstock rubber nursery. This section was a sequel from the training section above and was allowed only for the members of farmer group. Farmers grafting skills were expected to be improved by grafting the rootstock every 1 or 2 week in 3 months. Farmers were grafted the rootstock that they have maintained for 9 months. After the grafting process ended, the clonal rubber seedlings produced from FG nursery were distributed to all members of the farmer group based on an agreement they made in farmer group meeting. ICRAF provide material for entres (scions) to be grafted to the rootstock. ICRAF staffs monitored the grafting process and provide consultation if necessary.

Generally, farmers were enthusiast in learning to produce rubber clonal material though they were also realized that it needs time and effort in producing it. Obstacles were encountered by the farmer group (mostly internal affairs problems) during the nursery maintenance process, however farmer groups were able to confront the obstacles. Role of the head of the farmer group is fundamental in maintain the continuity of nursery maintenance activities. From the training series in producing clonal material, farmers also learned the advantage 
and disadvantage in working by group. Rubber nursery progresses and farmers responses in each village were varied mostly due to the different social and economy status per village:

(a) Sibulan-bulan is the most advance in rubber nursery construction and clonal rubber production due to their good group management. Of 5 villages, women participation in rubber nursery construction was dominant only in Sibulan-bulan village. Approximately $60-70 \%$ of the active Sibulan-bulan Farmer Group members were women.

(b) WEK1 is the most advance in adopting the knowledge. One month after the training at the Sungai Putih Rubber Research Institute, spontaneous adoption of rubber nursery technology was occurring in WEK1. Farmers were independently establishing their own rubber nursery garden. In August 2006, we have identified 4 new private rubber nurseries nearby the project organized village rubber nursery. Farmers who have been trained in Sungai Putih have inspired other farmers to adopt clonal rubber nursery technology for commercial purposes.

(c) Hutagurgur and Aek Nabara have the same level of progress in rubber nursery construction though they have different obstacles to maintain the process in producing the clonal rubber.

(d) Sitandiang has the least progress in rubber nursery construction mostly due to the severe village internal conflicts that were existed in the middle of the program.

Details achievements and process in each step of the training series are discussed below:

\section{Rubber nursery construction}

As explained above, the rubber nursery construction was conducted in 2 main steps, i.e. the training and the field practice.

\subsection{Training}

The training series to support the rubber nursery construction were conducted in 3 sections:

(i) Informal training for the initial step on constructing the rootstock rubber nursery (April 2006). ICRAF staffs facilitated the informal training that was conducted during the weekly monitoring (biweekly for villages with difficult accessibility) for 1 month. Simple field guide manual to construct rootstock rubber nursery was distributed to each member of the farmer group. Subjects in the training included seeds germination handling, method to transfer the germinated seedlings, method to fertilize and weed the seedlings in the first month. Participants in the training were mostly from the farmer group. Informal discussion was also conducted with the other villagers (non farmer group members) who interested to learn.

(ii) Training at Sungai Putih Rubber Research Institute (17-19 July 2006). Sungai Putih Rubber Research Institute is government research institute for rubber that has been established in Sungai Putih, North Sumatra (400 km from Batang Toru area) since 1980-ies. The Sungai Putih rubber research institute provided training packages mostly on domestication and latex harvesting aspects. Sending some of Batang Toru farmers to Sungai Putih rubber research institute (Sungai Putih RRI) will benefit the 
rubber nursery construction process. Therefore, 3 farmers per focused village were selected by the criteria: (i) have good capability in sharing knowledge with others, (ii) more knowledgeable in rubber nursery, (iii) proposed by their group through voting, (iv) proportion of men and women were also considered, (v) voluntary willing to be sent to Sungai Putih RRI for the training. Those 15 selected farmers (potential farmers) were sent to Sungai Putih RRI on 17-19 July 2006 for a 3 days intensive training. The objective of the training was to enhance farmer's knowledge and skills in producing clonal rubber material and enhance their capability as local trainers. An additional objective of the training was to develop a forum where farmers of the five focused villages would get to know each other and discuss/share idea on conservation-livelihood issues.

Methods used in the training were combined both classroom instruction and practical field sessions (at a 30:70 ratio, respectively). Training subjects were included (i) introduction to rubber clonals, (ii) seeds production and nursery establishment, (iii) entres (scions) garden establishment, (iv) grafting training, (v) nursery pest and diseases handling, and (vi) nursery maintenance (e.g. fertilizing, weeding frequency). Training materials were provided by the Rubber Research Institute, though some of the materials were not comprehensible for farmers level. The training process was leaded by 3 rubber nursery specialists from Rubber Research Institute of Sungai Putih, North Sumatra. ICRAF staffs monitored the process during the training sessions.

All those 15 participant farmers were keen in learning the subjects of the training. They were grateful in have been given a chance to learn new things that they considered to be useful to enhance their livelihood. Those 15 farmers were promised to share the knowledge they have gained at the training to the other member of the farmer group and other villagers. Of those 15 farmers participated in the training, only 1 farmer (Sopian Lubis) who was directly establishing his individual rubber clonal nursery after the training. Currently, Sopian Lubis sells his rubber clonal material from his $1 / 4$ ha rubber nursery as his alternative livelihood (income). Other farmers who owned limited land also follow Sopian Lubis livelihood strategy by producing clonal material for commercial as an alternative livelihood.

(iii) Informal farmer to farmer training (July-August 2006)

Farmer to farmer training method was applied to transfer the knowledge from The Rubber Research Institute to the farmers through the potential farmers that have been trained for 3 days at Sungai Putih RRI. On an informal discussion that was conducted during routine farmer group meeting, those 3 farmers per village were share the knowledge they have gained at Sungai Putih RRI to other farmers who want to know more about the rubber nursery construction, its maintenance and its potential prospect as alternative livelihood. Farmer to farmer training method was proved to be effective since communication is more simple and comprehensive between farmers with the same background and culture.

In some villages, the farmers who have been trained at Sungai Putih RRI didn't directly share their knowledge. As a facilitator, during monthly monitoring, ICRAF staffs stimulated those farmers, in flexible and creative way, so that those farmers were motivated to transfer the knowledge they have gained to other farmers. 


\subsection{Field practice}

Producing clonal rubber considered by the farmers as new technology to improve the latex production from their rubber agroforest garden. Farmers are keen in adopting the new technology to improve their economical status. Learning by doing method (field practice) was identified as the effective way for farmers to adopt the technology to produce clonal rubber, therefore ICRAF supported materials and consultations for farmers that converged in farmer group to construct 1 rootstock rubber nursery and 1 entres garden per village as part of the process to produce clonal rubber. The farmer group provided a $1 / 4$ to $1 / 2$ ha land for the rootstock rubber nursery and a $1 / 4$ ha for entres garden per village. Detail information on rootstock rubber nursery construction and entres garden construction are explained below:

\subsubsection{Rootstock rubber nursery}

Rootstock means a stock for grafting consisting of a root or a piece of root. In producing qualified clonal rubber, quality of rootstock seedling needs to be remarked. Rubber research institute recommended the good clone types for rootstock rubber are GT1 and PB260. Therefore, ICRAF gave 20,000 rubber seeds of GT1 clone per village for rootstock to produce clonal rubber in Batang Toru area.

Rootstock rubber nursery construction was initiated by asking the farmer groups to provide a clear land (1/4-1/2 ha) for the nursery and also seed-beds to sow the 20,000 rubber seeds. ICRAF staffs guided the farmers from the seed sowing process until the seeds germinate and ready to be planted in the nursery. Rubber seeds were distributed in each of the village on 7-9 April 2006. Farmers in all villages were enthusiast with the rubber nursery construction; they sowed the seeds directly after seeds were distributed to them. Dynamic responses in each of the village were evolved particularly during the first month. Bad experience from past projects that has been implemented in the area has caused some farmers arguing ICRAF assistances. A summary of nursery status in the first month as follows:

\section{a. WEK I village}

At the initial stage WEK I nursery is the most advanced, probably because its location near the PTPN III plantation. The nursery is located on a half hectare plot of a group member near the Batang Toru River. No payment for the land for land use is required. Previously, the land was planted by vegetables and cassava. Approximately $80-90 \%$ of the seeds have germinated and been transplanted to the nursery as of 21 April 2006.

\section{b. Sibulan-bulan village}

The nursery is located on a half hectare plot of a group member. The group rents the land for 30 kaleng (cans) of rice (1 kaleng equals approximately $16 \mathrm{~kg}$ ). Previously the site was a rice paddy. Approximately $70-80 \%$ of the seeds have germinated and been transplanted to the nursery as of 24 April 2006. The Sibulan-bulan group is the only farmer group with active women members, $70 \%$ of members are women.

\section{c. Sitandiang village}

The nursery is located on a quarter hectare plot of a group member. Previously the site was a mixed rice paddy rice and durian garden. Approximately $60-70 \%$ of seeds have germinated and been transferred to the nursery by 28 April 2006. 


\section{d. Hutagurgur village}

The nursery is located on a quarter hectare plot of a group member. Previously the site was a banana garden, some banana trees still occur in the area. Only $40-50 \%$ of the seeds germinated, because the farmer group failed to follow the agreed upon procedures. Germinated seeds were transferred to the nursery on 28 April 2006 with help from the district extension agents (PPL)

\section{e. Aek Nabara village}

The Aek Nabara rubber nursery is the least developed, this community is very poor and faces several challenges, including land access conflict. The nursery is located on a quarter hectare plot of a group member. Previously it was volleyball field and still contains several big durian trees (diameters of 20-40 cm). This land was chosen because there is no other land that can be used for the nursery. Farmers delayed sowing the seed received for more than 2 weeks. As of 28 April 2006, only 5-10\% of the seeds had germinated. Aek Nabara farmers demonstrate less motivation then other communities. This is likely a result of past experience with outside programs that have engaged the community but provided no benefit to the people. Understandably the community now displays antipathy any outside institution who enter the village. This will require hard work to overcome.

Farmer group was formed at least 2 weeks before the rubber nursery construction began, because the farmer group will responsible in managing the rootstock rubber nursery. The FG arranged the nursery maintenance schedule after the germinated seeds transplanted to the nursery. ICRAF staffs monitored the rubber nursery maintenance per month in each of the village. Series of activities were conducted in each of the village to construct and maintain the nursery until the rootstock seedlings ready to be grafted as listed in Table 4 . After 8 months, the rootstock seedlings were expected ready to be grafted. Number of rootstock seedlings that were available to be grafted in each of the villages: (i) Sibulanbulan: 11000 seedlings; (ii) WEK1: 8000 seedlings (pig damaged); (iii) Hutagurgur: 4000 seedlings (half of the seedlings were stolen); (iv) Sitandiang: 500 seedlings (most of the seedlings were competing with weeds); (v) Aek Nabara: 3000 seedlings. 
Table 4. Activities related to rootstock rubber nursery construction in Batang Toru area

\begin{tabular}{|c|c|c|}
\hline TIME (Month) & ACTIVITIES & PEST AND DISEASE \\
\hline $0-0.5^{\text {th }}$ & $\begin{array}{l}\text { Land preparation (cleared the area, removed } \\
\text { all roots/plant materials that can caused the } \\
\text { White Rootrot disease) } \\
\text { Sowing the rubber seeds in the seedbeds } \\
\text { containing sandy soils with the design of the } \\
\text { seedbeds as in the picture below: }\end{array}$ & None \\
\hline $0.5-1^{\mathrm{st}}$ & $\begin{array}{l}\text { After } 7 \text { days, the sown seeds were germinated } \\
\text { and ready to be transplanted to the nursery field. } \\
\text { Germinated seeds must be directly transplanted. } \\
\text { The transplanting process was completed in 2-4 } \\
\text { weeks. }\end{array}$ & None \\
\hline $1-1.5^{\text {th }}$ & $\begin{array}{l}\text { All germinated seeds have been transplanted to } \\
\text { the nursery. Fertilizers (Urea/N-fertilizer and SP- } \\
36 / \text { P-fertilizer by the dosage of } 100 \text { gram } / 20 \mathrm{~m}^{2} \\
\text { per fertilizer type) were applied } 2 \text { weeks after all } \\
\text { rubber plants transplanted to the nursery. }\end{array}$ & \\
\hline $1.5^{\text {th }}-9^{\text {th }}:$ & $\begin{array}{l}\text { Maintenance: } \\
\text { Month } 1.5^{\text {th }}-4^{\text {th }} \text { : Intense maintenance (weekly } \\
\text { weeding) } \\
\text { Month } 4^{\text {th }}-9^{\text {th }}: \text { Less intensive maintenance } \\
\text { (monthly weeding) } \\
\text { Fertilizers (Urea/N-fertilizers and SP-36/P- } \\
\text { fertilizers) were applied on: } \\
\text { a. Month } 3^{\text {rd }} \text { : dosages were } 1.5 \text { times } \\
\text { higher than in the } 1^{\text {st }} \text { month } \\
\text { b. Month } 5^{\text {th }} \text { : dosages were } 2.5 \text { times higher } \\
\text { than in the } 3^{\text {rd }} \text { month } \\
\text { Number of rootstock seedlings available: } \\
\text { (i) Sibulan-bulan: } 12000 \text { seedlings; } \\
\text { (ii) WEK1: } 10000 \text { seedlings; } \\
\text { (iii) Hutagurgur: } 8000 \text { seedlings; } \\
\text { (iv) Sitandiang: } 5000 \text { seedlings with poor } \\
\text { condition (no leaves, leaves were eaten } \\
\text { by grasshoppers and monkeys); } \\
\text { (v) Aek Nabara: } 4000 \text { seedlings. }\end{array}$ & $\begin{array}{l}\text { Pests attack and diseases that were } \\
\text { appeared: } \\
\text { a. Month } 3^{\text {rd }} \text { : Worm earth has caused } \\
\text { about } 5 \% \text { of the seedlings died. } \\
\text { Tricoderma was also applied to } \\
\text { prevent white root disease. } \\
\text { b. Month } 6^{\text {th }} \text { : In most of the nursery, } \\
\text { earth worms have becoming the } \\
\text { main pest and are eating the roots of } \\
\text { seedlings. Curater was applied to } \\
\text { cure and prevent it from further } \\
\text { spreading. } \\
\text { c. Month } 8^{\text {th }}-9^{\text {th }} \text { : Insects (fleas) were } \\
\text { attacking ca. } 10 \% \text { of the rootstock } \\
\text { seedlings, prevention has been made } \\
\text { by applying curater in the infected } \\
\text { trees. } \\
\text { Leaves diseases (Colletotrichum) } \\
\text { were encountered in some of the } \\
\text { seedlings. Dithane M- } 45 \text { was } \\
\text { sprayed to cure the leaves diseases. }\end{array}$ \\
\hline
\end{tabular}




\begin{tabular}{|l|l|l|}
\hline $9^{\text {th }}-10^{\text {th }}$ & $\begin{array}{l}\text { Fertilizers (Urea and SP-36, by the dosages 2 } \\
\text { times higher than the } 5^{\text {th }} \text { month) were applied 1 } \\
\text { month before the rootstock seedlings were } \\
\text { grafted }\end{array}$ & None \\
\hline $10^{\text {th }}-13^{\text {th }}$ & Rootstock seedlings were grafted & None \\
\hline
\end{tabular}

Obstacles in constructing rootstock rubber nursery were evolved particularly during the nursery maintenance phase after the $4^{\text {th }}$ month. Internal conflicts that were evolving as group dynamic in all of the farmer groups, sometimes may stop the nursery maintenance activities. Farmer group that able to maintain their routine group meeting (at least 1 times per month), can reduce the impact of internal conflict to their nursery maintenance activity. Only in Sitandiang, the routine group meeting stopped in the month $6^{\text {th }}$, village and farmer group internal conflicts were identified as the main cause. This internal conflict in Sitandiang has also caused the unsuccessful grafting process.

\subsubsection{Budwood (Entres) garden construction}

Entres garden is a garden planted by seedlings of pure clone that will function as scions sources in the grafting process to produce clonal material, in this case clonal rubber. The seedlings that are planted in entres garden must have clear parental information. Entres garden should be planted near the rootstock nursery and should be established before or at the same time as the rootstock nursery establishment. Age of rootstock seedlings with the entres (scions) must be approximately the same in the grafting process, this particularly refer to same bark thickness and age.

One entres garden per village were planned to be constructed in each focus village, hence ICRAF provided grafting stock stumps from Sungai Putih Rubber Research Institute, fertilizers, polybags and consultations. Due to time constrain (limited timeframe of the project) and the available grafting stock stumps at Sungai Putih RRI, the entres garden establishment for this project was started 4 months after the rootstock nursery been established. Farmers need to do weekly maintainance in the first 3 months to the grafting stock stump that was planted in polybag. After the stump has 2 whorls leaves, the stumps were planted in entres garden by $1 \mathrm{~m}$ x $1 \mathrm{~m}$ space.

In all villages, entres garden was constructed in a private land belongs to one of the farmer group's member. The land was borrowed from the owner and will be returned after ca. 8 years, with an agreement that the owners may keep the standing rubber plants for production. All entres garden were finally established in the month $4^{\text {th }}$ (Table 5.). For further management, farmers were also trained to maintain the entres garden and 3 manual to construct and maintain rubber entres garden were distributed per village. Scions from the entres garden can be harvested in the first year and only farmer group members that have access to harvest the scions. If there are outsiders who requested scions for grafting, then an agreement between the outsiders with the farmer group needs to be negotiated. 
Table 5. Global monthly progress on entres garden construction generally in all focus villages in Batang Toru area

\begin{tabular}{|c|c|}
\hline Month & Description \\
\hline $1^{\text {st }}$ (Aug06) & $\begin{array}{l}\text { Grafting stock (mata tidur) stumps were distributed to all villages. Farmer } \\
\text { groups in Sibulan-bulan, Sitandiang, Hutagurgur, and WEK } 1 \text { each received } 110 \\
\text { 'PB260 stumps' and } 110 \text { 'BPM107 stumps'; Aek Nabara village that only } \\
\text { received } 80 \text { 'PB260 stumps' and } 80 \text { 'BPM107 stumps' as they responded slowly } \\
\text { to the rubber nursery establishment and their capacity remains less then the other } \\
\text { villages. } \\
\text { Each mata tidur stump was planted in a } 25 \mathrm{~cm} \mathrm{x} 40 \mathrm{~cm} \text { polybag. } \\
\square \text { Fertilizer (N-fertilizer and P-fertilizers, @ } 10-15 \text { gram/polybag) was applied } \\
\text { after } 1-2 \text { weeks. Tricoderma-sp ( } 50 \text { gram/polybag) was also applied for } \\
\text { preventing the infection of White Rot Root disease. } \\
\text { Two weeks after the stumps planted in the polybags, } 30-70 \% \text { of the stumps } \\
\text { (varying by village) flushing new bud from the scion. It is intended the entres } \\
\text { gardens will be established in September 2006, this will require stumps to have } \\
2 \text { whorls buds. }\end{array}$ \\
\hline $\begin{array}{l}2^{\text {nd }}-3^{\text {rd }} \\
\text { (Sep-Oct06) }\end{array}$ & $\begin{array}{l}\text { Stumps grafting stock (mata tidur) were growing well in all villages, except for } \\
\text { Sitandiang. ICRAF staffs have informed the Sitandiang FG how to improve the } \\
\text { growth of their stumps. The FG has promised to improve the management. } \\
\text { Disease: In Aek Nabara a new disease occurred on rubber stumps. The disease } \\
\text { causes new leaves to desiccate and new bud to rot from top to bottom. It is } \\
\text { suspected that the cause is a virus from banana trees ( } 50 \mathrm{~m} \text { away from the } \\
\text { stumps). ICRAF staffs have informed the FG to remove the healthy stumps to } \\
\text { other area but no action made so far from the Aek Nabara farmer group. The } \\
\text { same or similar disease was previously identified at WEK I nursery, which has } \\
\text { banana trees nearby the nursery. The symptom in banana was initiated by } \\
\text { yellowing leaves and ended by rotten trunk. }\end{array}$ \\
\hline $4^{\text {th }}$ (Nov06) & $\begin{array}{l}\text { Most of the stumps in } 3 \text { villages (Sibulan-bulan, WEK1 and Hutagurgur) have } \\
\text { been planted in an area relatively nearby the current rootstock nursery. } \\
\text { Stump for entres garden in other } 2 \text { villages (Sitandiang and Aek Nabara) were } \\
\text { dying because of lacking maintenance from the FG member. } \\
\text { Until end of November 2006, the percentage of the living stumps in each village } \\
\text { is } 70 \% \text { in Sibulan-bulan, } 85 \% \text { in Hutagurgur, } 70 \% \text { in WEK1, } 10 \% \text { in Sitandiang } \\
\text { and Aek Nabara. }\end{array}$ \\
\hline $\begin{array}{l}5^{\text {th }}-6^{\text {th }} \\
\text { (Dec06- } \\
\text { Jan07) }\end{array}$ & $\begin{array}{l}\text { Most of the work in establishing the entres garden has been completed in } 3 \text { villages } \\
\text { (Sibulan-bulan, WEK } 1 \text { and Hutagurgur), and fertilizers+trichoderma sp were applied } \\
2 \text { weeks after the seedlings planted. In Sitandiang and Aek nabara rubber nurseries } \\
\text { with poor survival percentage of the stumps for entres garden, none of the stump has } \\
\text { been planted. }\end{array}$ \\
\hline $7^{\text {th }}($ Feb07) & $\begin{array}{l}\text { Entres gardens have been successfully established in each of the } 3 \text { villages (i.e. } \\
\text { Sibulan-bulan, Hutagurgur and WEK1) and managed by FG. In Aek Nabara, the } \\
\text { seedlings for entres gardens were distributed to each of the farmer group members. } \\
\text { The farmer group in Aek Nabara has decided to manage entres gardens per person. } \\
\text { While in Sitandiang, none of the seedling have yet been planted in entres gardens. }\end{array}$ \\
\hline $8^{\text {th }}$ (Mar07) & $\begin{array}{l}\text { Fertilizers ( } 50 \mathrm{~kg} \text { Urea and } 50 \mathrm{~kg} \text { SP-36) for entres garden and rootstock seedlings } \\
\text { were distributed to each of the village to be applied per } 6 \text { months. }\end{array}$ \\
\hline
\end{tabular}

Performance of the entres garden is various in each of the village, particularly related to the frequency of gotong royong (group labor contribution) by the farmer group (FG). Of 5 expected entres garden only 3 were successfully established, i.e.: 


\section{(i) Sibulan-bulan village}

Entres garden was constructed in a private land ca. 10 meter away from the current rootstock nursery. The land is located in a steep area (with slope ca. 30\%), therefore the grafting stock seedlings were planted with terrace system. Previously the land was bushes and has been abandoned. Biweekly to monthly routine maintenance has been applied to the entres garden by the farmer group. Of 220 grafting rootstock stumps, only $70 \%$ that survived and able to be planted and maintained in the entres garden. Farmers of Sibulanbulan are planning to use the scions of their entres garden to grafted seedlings they will produce in the second phase of the rootstock rubber nursery funded by their-own initiative and extending their current rootstock rubber nursery.

\section{(ii) WEK1 village}

Entres garden was constructed in a flat land ca. $300 \mathrm{~m}$ away from the current rootstock nursery. Previously the land was bushes and has been abandoned. Monthly routine maintenance has consistently been applied to the entres garden by the farmer group. Percentage of survival of the distributed stumps was $70 \%$ of 220 distributed stumps. Compare to the other 2 entres garden (Sibulan-bulan and Hutagurgur), WEK 1's perform the best growth due its soil types and slope. Farmers of WEK1 are planning to use the scions from their entres garden for their private nursery that has been spontaneously developed after they adopt the knowledge from the group rootstock rubber nursery construction. Farmers of WEK1 prefer to have private rootstock rubber nursery while they prefer to have the entres garden be managed by group.

\section{(iii) Hutagurgur village}

Entres garden was located in a relatively flat area in the settlement area and ca. $500 \mathrm{~m}$ away from the current rootstock rubber nursery. Previously the land was a cacao home garden. Monthly maintenance was applied to the entres garden by the farmer group. Percentage of grafting rootstock stumps that were able to be planted in the entres garden was $85 \%$ of 220 distributed stumps. The seedlings in Hutagurgur entres garden grew at the same rate and performance as the seedlings in Sibulan-bulan's. By the promising local market to sale rubber clonal seedlings in Hutagurgur, farmers are planning to build much bigger rootstock rubber nursery maintained by group in a different area as the current rootstock rubber nursery. The new rootstock rubber nursery is planned to be constructed ca. $50 \mathrm{~m}$ from the entres garden to simplify the maintenance. Farmers intend to sale the next clonal rubber seedlings they produced.

Obstacles in constructing the entres garden particularly emerged in the other 2 villages, i.e.:

\section{a. Sitandiang case}

Of 220 stumps of the grafting stock that were distributed to the Sitandiang farmers, none was well maintained hence none entres garden was established at the end of the program.

Obstacles identified by the Sitandiang farmer group in establishing an entres garden were: (i) no available free land to construct the village's entres garden close to the village, and (ii) the farmer group an internal conflict in the farmer group that emerged at the same time as the paddy harvesting and other more important farmers' livelihood activities. Those obstacles have decreased farmer's motivation to maintain the entres garden and also the 
rootstock rubber nursery. Hence, farmers decided to ignore the stumps they have been planted in the polybags.

\section{b. Aek Nabara case}

Entres garden construction also could not be implemented in Aek Nabara; no available free land to construct the entres garden is becoming the main reason delivered by the farmers. Therefore, farmer group decided to distribute equally the grafting stock stumps to the FG members. Same as for Sitandiang, the less farmers' motivation mostly related to the village location, the more isolated the village the less motivation to produce the rubber clonal seedlings, because farmers couldn't see the potential/economical prospect to develop it (this was compare with the other 3 villages).

\section{Rubber grafting training}

Simple method in producing the clonal rubber is by grafting technique. Grafting is a plant propagation method of widely used in horticulture, where the tissues of one plant are encouraged to fuse with those of another. It is most commonly used for the propagation of trees and shrubs grown commercially. In most cases, one plant is selected for its roots, and this is called the stock or rootstock. The other plant is selected for its stems, leaves, flowers, or fruits and is called the scion. The rootstock and the scion should approximately come from tissue of the same age.

For rubber, there are 2 techniques of grafting, green grafting (for 3-4 months tissues) and brown grafting (for 8-9 months tissues). The most widely used is the brown grafting because its successful percentage is higher than green grafting. The rubber scion comes from buds in the stem, and was harvested from the entres garden. Rubber scions will be fused with the rootstock tissues in 3 weeks, therefore after 3 weeks the plastic band should be removed from the grafting scars. The grafted rubber needs to be harvested at least 2.5 weeks after the plastic band removal. After 2 weeks, the rubber shoots need to be cut $5 \mathrm{~cm}$ from the grafting scars, and let the seedlings without shoot for at least 5 days. After 5 days, the rootstock seedling can be pulled from ground and having its root cut $30 \mathrm{~cm}$ from the upper limit of the root. Rubber grafted seedlings usually harvested as stump material.

Rubber grafting technique has widely known and used by farmers in many places in Sumatra, but for Batang Toru's farmers the technique considered as new knowledge and skill. Due to the low Batang Toru farmers' knowledge and skills on vegetative propagation techniques, it is a priority to conduct rubber grafting training to produce high quality clonal rubber material. Therefore, a 2-3 days rubber grafting training was conducted in all focused village from mid January 2007 to end of March 2007 (Table 6.), with the objectives: (i) to graft the available rubber rootstock seedlings, (ii) to share knowledge and experience in managing FG to produce clonal rubber from more skilled farmers of other villages. ICRAF provided the scions from Sungai Putih Rubber Research Institute, to graft all available rootstock seedlings in the rubber rootstock nursery, since the newly established entres garden couldn't afford to provide scions for all the available rootstock seedlings. Tools and materials for the grafting (i.e. grafting knives and grafting plastics) were also provided by ICRAF. 
Table 6. Participants of the grafting training in five focused villages in Batang Toru area

\begin{tabular}{|c|c|c|c|}
\hline Village name & Date & $\begin{array}{c}\text { Number of } \\
\text { participants }\end{array}$ & Note \\
\hline Sibulan-bulan & $\begin{array}{l}22-24 \quad \text { Jan } \\
2007\end{array}$ & $\begin{array}{l}37 \text { (10 females } \\
\text { and } 27 \text { males) }\end{array}$ & $\begin{array}{l}8 \text { persons of the participants come from } \\
\text { other village from other subdistrict } \\
\text { (Simanampang village, Pahae Julu } \\
\text { subdistrict) } \\
4 \text { extension officers ( } 1 \text { from Purba Tua } \\
\text { subdistrict, } 2 \text { from Simangumban } \\
\text { subdistrict and } 1 \text { from Pahae Julu } \\
\text { subdistrict) attended the training. } \\
150 \text { meters scions of IRR39 clonal rubber } \\
\text { were grafted to the available rootstock } \\
\text { seedlings }\end{array}$ \\
\hline WEK1 & $\begin{array}{l}30 \text { Jan }-1 \\
\text { Feb } 2007\end{array}$ & $\begin{array}{l}29 \text { (1 female } \\
\text { and } 28 \text { males) }\end{array}$ & $\begin{array}{l}140 \text { meters scions of IRR39 clonal rubber } \\
\text { were grafted to the available rootstock } \\
\text { seedlings }\end{array}$ \\
\hline Hutagurgur & $\begin{array}{ll}15-16 \quad \text { Feb } \\
2007\end{array}$ & $\begin{array}{l}12 \text { (5 females } \\
\text { and } 7 \text { males) }\end{array}$ & $\begin{array}{l}30 \text { meters scions (entres) of IRR39 clonal } \\
\text { rubber were grafted to the available rootstock } \\
\text { seedlings }\end{array}$ \\
\hline Aek Nabara & $\begin{array}{l}28 \text { Feb - } 1 \\
\text { Mar } 2007\end{array}$ & 12 (all males) & $\begin{array}{l}30 \text { meters of scions IRR39 and } 30 \text { meters of } \\
\text { PB260 scions were grafted to the available } \\
\text { rootstock seedlings }\end{array}$ \\
\hline Sitandiang & $\begin{array}{l}20-21 \quad \text { Mar } \\
2007\end{array}$ & $\begin{array}{l}14 \text { (11 males } \\
\text { and } 3 \text { females) }\end{array}$ & $\begin{array}{l}60 \text { meters of scions IRR39 were grafted to the } \\
\text { rootstock seedlings available in Sitandiang's } \\
\text { rubber nursery. }\end{array}$ \\
\hline
\end{tabular}

The 2-3 days grafting training was a combination between 1-2 hours theoretical explanation on the first day, with 2-2.5 days field practice (Table 7.). Target participants of the training were divided into 2 groups, i.e. general participants and FG members. In the first day, the training was for both groups, while in the second and third day the target participants were only the FG members who will harvest the clonal rubber they have expected for 9 months.

Table 7. Grafting training schedule that was conducted in Batang Toru area

\begin{tabular}{|l|l|l|}
\hline \multicolumn{1}{|c|}{ Day } & \multicolumn{1}{c|}{ Subjects } & \multicolumn{1}{c|}{$\begin{array}{c}\text { Target } \\
\text { Participants }\end{array}$} \\
\hline 1 & $\begin{array}{l}\text { 1. Vegetative propagation theory (in class training: 1-2 } \\
\text { hours) by ICRAF staff } \\
\text { 2. Discussion on the Grafting technique (in class training: } \\
\text { 1-2 hours) by Local expert (Arifin Khaeran) }\end{array}$ & $\begin{array}{l}\text { General } \\
\text { participants: } \\
\text { farmers that were } \\
\text { interested with the }\end{array}$ \\
& $\begin{array}{l}\text { 3. Practice grafting in the village rubber nursery (3 hours) } \\
\text { 4. Sharing knowledge of grafting process that has been } \\
\text { conducted by other farmers that were invited as local } \\
\text { expert from other area, also share experience in } \\
\text { managing FG. }\end{array}$ & \\
\hline 2 and 3 & Managing grafting process per farmer group & \\
\hline
\end{tabular}

Farmer to farmer method to transfer knowledge has been proved in many places to be effective, hence the method was applied to transfer knowledge about grafting technique and managing farmer group to produce grafted rubber material in Batang Toru area. Local experts (who are also farmers from the area) were being involved in the training process (Figure 4.), ICRAF staffs participated as facilitators in the training. The grafting training 
was conducted at first in Sibulan-bulan because the Sibulan-bulan has the most advance rootstock nursery (regarding to its quantity and quality). Farmers in the Sibulan-bulan area were trained by 2 professional grafters from Sungai Putih Rubber Research Institute and 1 professional grafter from Batang Toru area. In the Sibulan-bulan FG members, 7 persons were identified as the most advance in learning grafting technique. Those 7 well trained Sibulan-bulan FG members were then invited as local experts for the next grafting training at WEK1. In WEK1 FG members, 7 well trained FG members were also been identified and were invited as local experts for the grafting training at Hutagurgur. From Sibulan-bulan, WEK1 and Hutagurgur (the more advance FG compare to Aek Nabara and Sitandiang), 3 skilled farmers were identified and were invited as local expert for the grafting training at Aek Nabara and Sitandiang. We invited less local experts for grafting training at Aek Nabara and Sitandiang due to the difficult access to those 2 villages.

Farmer to farmer method not only useful to transfer knowledge about grafting, but also has give farmers chance to see the progress and problems encountered by farmers in other focused villages. Farmers, who have seen progress and problems in other area, will automatically evaluated the progress made so far in their origin farmer group and village, and passed the information they heard and seen in other villages to their friends in their origin village. Farmer to farmer method also has allowed farmers from different villages to communicate themselves and initiated farmers' informal networking, e.g. network to market their clonal rubber seedlings. 


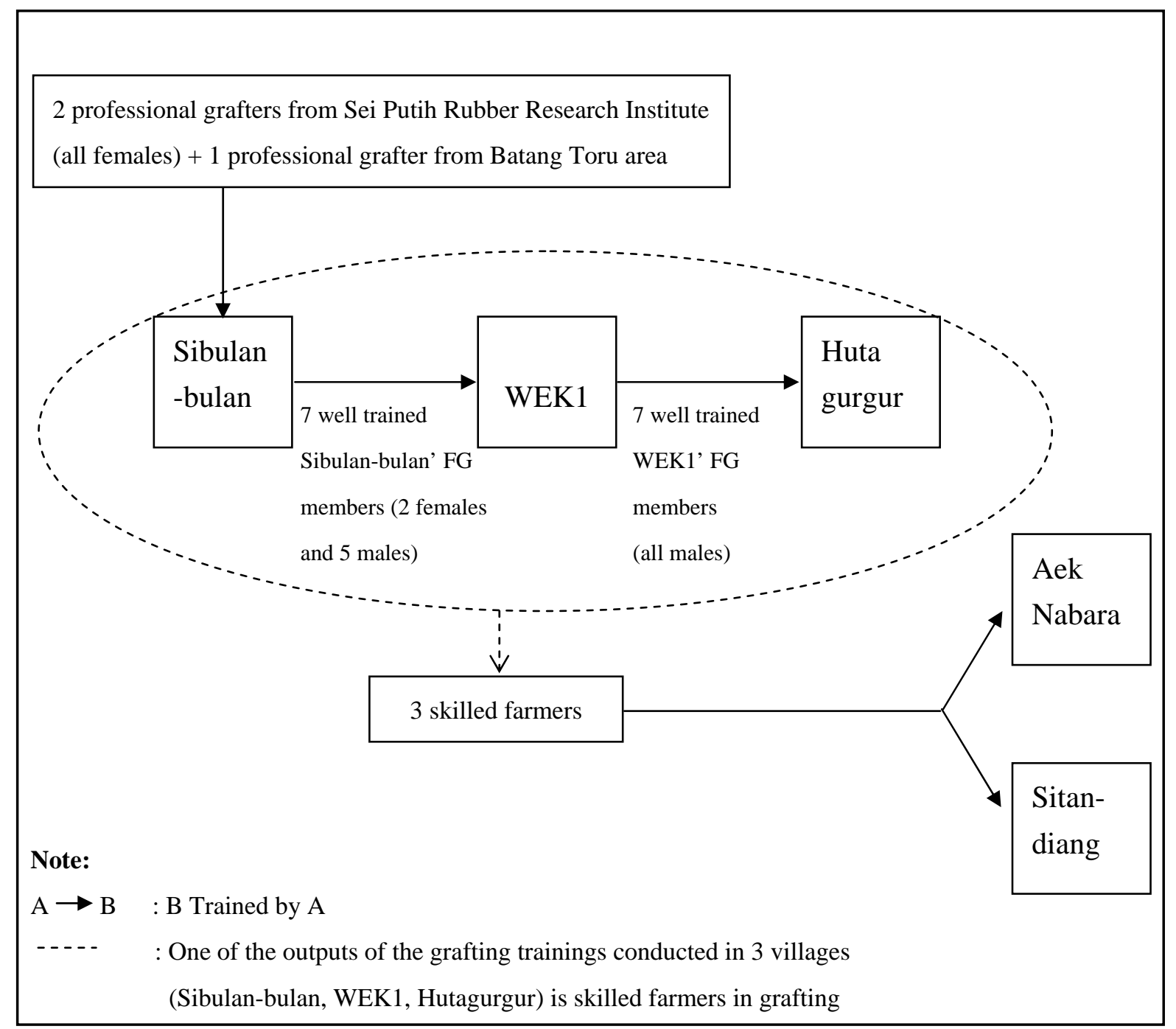

Figure 4. Scheme of Farmer to Farmer transfer knowledge process in producing clonal rubber in Batang Toru program

\section{Grafting Process per Farmer Group}

After the 2-3 days training, farmers were urged to graft the rootstock that they have nursed for ca. 9 months. Between January and April 2007, rubber grafting activities have been conducted in each farmer group. The quantity of entres (scions) received by each village varied based on the available rootstock seedlings in their respective nurseries (Table 8.). Rubber grafting activities in all villages were completed by the third week of April 2007. Farmers then began to harvest the rubber clonal seedlings in the beginning of May 2007.

Grafting activities in each village were conducted by the Farmer Group members. In villages with more than 5000 rootstock seedlings and FG members more than 20 persons (Sibulan-bulan and WEK1 village), managed their grafting process by forming 2-3 small groups leaded by 1 person who was responsible in monitoring the grafting process and also have to report the grafting process of their small group to the head of FG. While in other villages, the head of FG directly leaded and monitored the grafting process. Of 5 villages, 4 villages have successfully completed grafting activities, i.e. Aek Nabara, Sibulan-bulan, 
WEK1 and Hutagurgur (Table 9). Only in Sitandiang the grafting activities couldn't successfully implemented due to the unsolved village internal problem which has decreased farmers' motivation to graft their rootstock seedlings.

Table 8. Number of rubber entres (scions) and its clone types that were distributed to each focus village in Batang Toru area

\begin{tabular}{|c|c|c|c|c|c|}
\hline VILLAGE & $\begin{array}{l}\text { CLONE } \\
\text { TYPE }\end{array}$ & $\begin{array}{l}\text { NUMBERS } \\
\text { (meter) }\end{array}$ & VILLAGE & $\begin{array}{c}\text { CLONE } \\
\text { TYPE }\end{array}$ & $\begin{array}{c}\text { NUMBERS } \\
\text { (meter) }\end{array}$ \\
\hline \multirow[t]{6}{*}{$\begin{array}{l}\text { SIBULAN- } \\
\text { BULAN }\end{array}$} & IRR39 & 260 & \multirow[t]{2}{*}{ SITANDIANG } & IRR39 & 30 \\
\hline & PB260 & 180 & & $\begin{array}{l}\text { PB260 } \\
\end{array}$ & 30 \\
\hline & BPM1 & 130 & \multirow[t]{3}{*}{ AEK NABARA } & IRR39 & 60 \\
\hline & BPM24 & 50 & & PB260 & 30 \\
\hline & PB340 & 80 & & PB340 & 25 \\
\hline & RRIC100 & 130 & \multirow[t]{3}{*}{ HUTAGURGUR } & IRR39 & 30 \\
\hline \multirow[t]{6}{*}{ WEK1 } & IRR39 & 560 & & PB260 & 60 \\
\hline & PB260 & 200 & & RRIC100 & 60 \\
\hline & BPM1 & 150 & & & \\
\hline & BPM24 & 75 & & & \\
\hline & PB340 & 80 & & & \\
\hline & RRIC100 & 225 & & & \\
\hline
\end{tabular}

Farmers were distributing the clonal rubber seedlings after they harvested. Distribution of clonal rubber seedlings depends on the mechanisms agreed by each farmer group. WEK1, Aek Nabara and Hutagurgur agreed to distribute the seedlings equally, meaning each of the members received the same number of seedlings. While Farmer Group in Sibulan-bulan was agreed to distribute the seedlings to each member received according to their attendance at weekly gotong royong activity over the previous year. Clonal seedlings distribution in Sibulan-bulan is the most interesting. Clonal seedlings were distributed to the FG members based on their presence record during gotong royong, weaknesses with this is sometimes there are people who didn't record their name while they were attending the gotong royong. The remaining ungrafted seedlings were also distributed to member according to the mechanism agreed by each farmer group. 
Table 9. Number of clonal seedlings produced from each focus village in Batang Toru area

\begin{tabular}{|c|c|c|c|c|c|}
\hline Village & $\begin{array}{l}\text { Entres } \\
\text { sticks } \\
(\mathbf{m})\end{array}$ & $\begin{array}{c}\begin{array}{c}\text { Number of } \\
\text { the }\end{array} \\
\text { available } \\
\text { rootstock } \\
\text { seedlings }\end{array}$ & $\begin{array}{c}\text { Total number } \\
\text { of produced } \\
\text { clonal } \\
\text { seedlings } \\
\text { (successful } \\
\text { percentage) }\end{array}$ & $\begin{array}{c}\text { Mechanism } \\
\text { of rubber } \\
\text { clonal } \\
\text { distribution }\end{array}$ & Notes \\
\hline $\begin{array}{l}\text { Sibulan- } \\
\text { bulan }\end{array}$ & 830 & 12000 & 3000 (36.1\%) & $\begin{array}{l}\text { Distributed } \\
\text { according to } \\
\text { labor } \\
\text { contribution } \\
\text { to the group }\end{array}$ & $\begin{array}{l}\text { Seedlings } \\
\text { distributed } \\
\text { according to } \\
\text { members } \\
\text { participation in } \\
\text { gotong royong } \\
\text { activities. The } \\
\text { minimum number } \\
\text { of seedlings } \\
\text { received by the } \\
\text { farmers is } 70 \text {, and } \\
\text { the maximum is } \\
150 \text { seedlings. }\end{array}$ \\
\hline WEK1 & 1290 & 8000 & $1363(10.6 \%)$ & $\begin{array}{l}\text { Equally } \\
\text { distributed }\end{array}$ & $\begin{array}{l}29 \text { members } \\
\text { received } 47 \text { clonal } \\
\text { seedlings }\end{array}$ \\
\hline $\begin{array}{l}\text { Aek } \\
\text { Nabara }\end{array}$ & 115 & 1500 & $870(75.6 \%)$ & $\begin{array}{l}\text { Equally } \\
\text { distributed }\end{array}$ & $\begin{array}{l}\text { Each FG member } \\
\text { (12 HH) received } \\
\text { more than } 200 \\
\text { clonal seedlings }\end{array}$ \\
\hline Hutagurgur & 150 & 1500 & $510(34 \%)$ & $\begin{array}{l}\text { Equally } \\
\text { distributed }\end{array}$ & $\begin{array}{l}\text { Each FG member } \\
(17 \mathrm{HH}) \text { received } \\
30 \text { clonal seedlings }\end{array}$ \\
\hline Sitandiang & 60 & 1000 & 0 & None & None yet \\
\hline
\end{tabular}

Grafting process in each village group required good cooperative between members of the FG. From its grafting successful percentage, Aek Nabara has the highest rate, i.e. 75.6\%, follow by Sibulan-bulan (36.1\%), Hutagurgur (34\%) and WEK 1 (10.6\%). Compare to grafting process in other ICRAF site (Bungo, Jambi and Sanggau, West Kalimantan), this successful percentage for Batang Toru case is normal, because the technique is new and farmers' skill level is various. Main point that was emphasized in this training is that farmers learn the process.

Grafting successful percentage may have close relation with number of members in the FG, the more members of the FG the less effective and efficient the grafting process. Effective number of FG members to graft the clonal rubber is $10-20$ persons. If the FG members more than 20 persons, it would be too hard to manage the grafting activities. Beside number of members in FG, other factors also have affected the grafting process activities per village, i.e.: 
1. Technical

(i) Limited entres (scions) availability in the area, therefore entres sticks were supplied from Sungai Putih Rubber Research Institute that is located ca. $300 \mathrm{~km}$ from the village.

(ii) In the Batang Toru grafting training, 5 rubber clonal were introduced, i.e. PB260, PB340, RRIC100, BPM1, BPM24, IRR39. Those clone types were selected based on its availability in the Rubber Research Institute and its compatibility with the Batang Toru climatic condition. Using more than 2 clone types in the grafting training for beginners has caused confusion in documenting and marking the trees, however farmers learnt that levels of grafting successful were different between clones.

2. Nature (shedding leaves)

Rubber grafting cannot be applied to trees that shedding its leaves. Leaves shedding was becoming the major constraint for the grafting activity in Sibulan-bulan, more than 50\% of the rootstock seedlings shed its leaves, therefore only about 3000 seedlings ( $25 \%$ of 12000 rootstock seedling) that can be grafted in the first month. The other seedlings were grafted after its new flushing shoot becoming mature leaves. While In WEK1, only 50\% of the rootstock seedlings shed its leaves, therefore about 4000 (of 8000) seedlings can be grafted in the first month.

3. FG management/leadership type

Sitandiang, rubber grafting activity could not be conducted in Sitandiang due to the internal problems in the village which have resulted in the farmer group members neglecting their rubber nursery 


\section{Appendix 2. Training on agroforest garden management: replanting techniques that can be applied in Batang Toru area}

Mosaic of various types of agroforest system in Batang Toru area is formed through long process that began ca. more than 100 years ago when farmers were constructing their first garden in the forested area. Styrax (Styrax spp.) and Rubber (Hevea brasiliensis) were 2 main tree crops species that were planted and harvested by farmers to support their livelihood. Other tree species (mostly fruit trees) were also planted by the farmers, e.g. durian, mangostan. Farmers also maintained other tree species that grew naturally as alternative source for their livelihood. The gardens were heritage from generation to generation. Up until now, farmers in Batang Toru area still depending their livelihood to the mixed tree based gardens (agroforest) that were created by their ancestors. Land use dynamics occurred in the mosaic landscape as describe in Figure 5.

Batang Toru's communities have high dependency to agroforest garden for their livelihood since more than 100 years ago up until now. Agroforest has been proven to provide not only income but also environmental services that benefiting the community. Unfortunately, compare to monocultural system, production of 1 single crop species in agroforest system is much lower. As the community’ economic demand increased, low agroforest production will be the main factor that would lead to the agroforest's land conversion to more monocultural system. Currently in some area, as rubber price increased, farmers began to intensify and rejuvenate their old rubber agroforest. Therefore it is important to introduce technology in enhancing agroforest production that compatible with maintaining the environmental services provided by the complex agroforest ecosystem. 


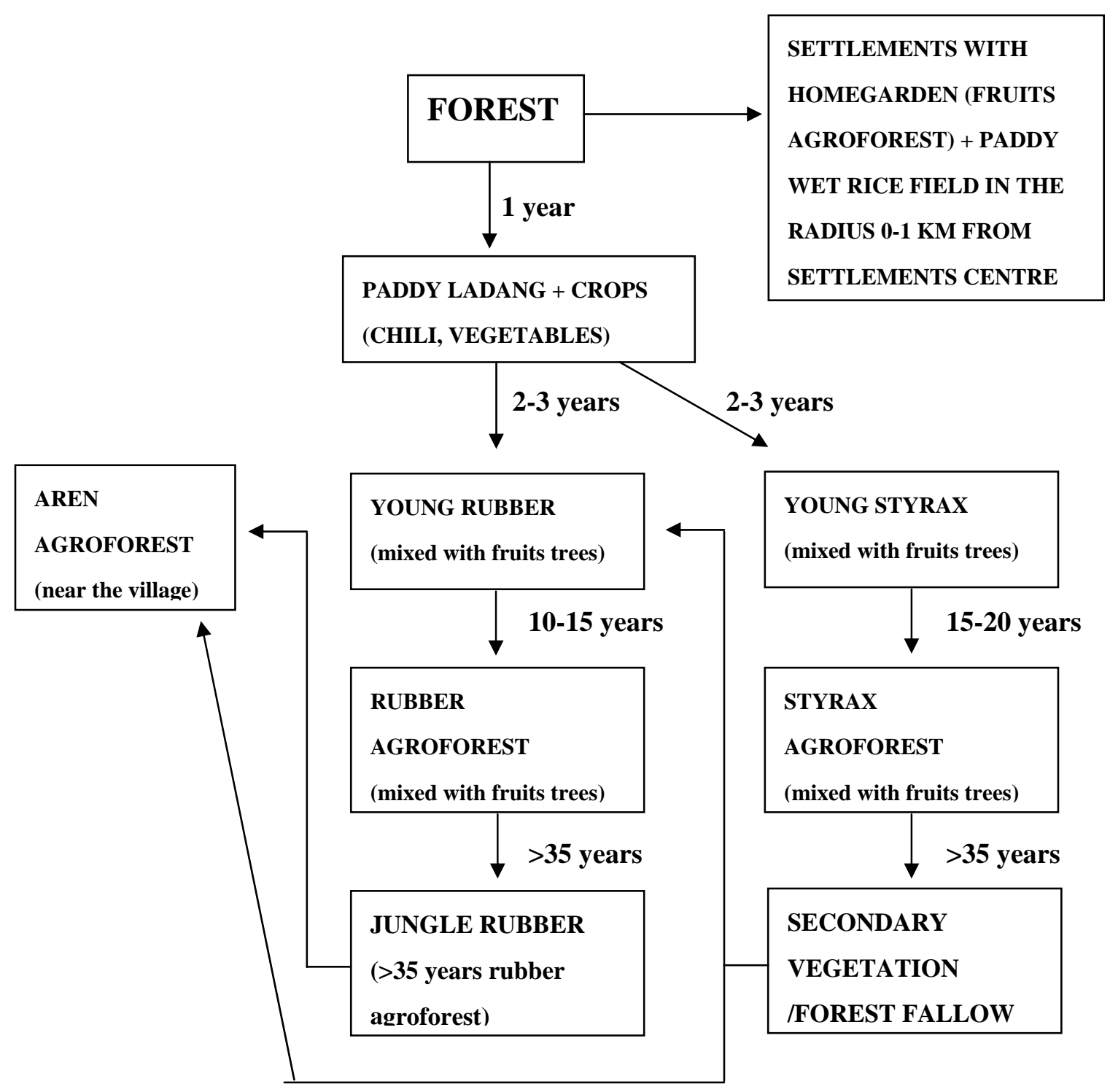

Figure 5. Land use dynamics in Batang Toru area

Enhancing agroforest production means improving its garden management and marketing aspects. Low production is mostly caused by the status of agroforest gardens in the Batang Toru area as being heritage and old (>50 years) with extensive management and less maintenance applied to the garden. Also unclear spacing distant between species, lacking knowledge about pest and disease handling and low based tree species density has affected the low production of agroforest products in Batang Toru area. On the marketing aspects, sophisticated market linkage in the area for agricultural commodity has affected the motivation of farmers to enhance the quality and quantity of their agroforest products. Market play major role in the standard quality of the products. Currently, farmers' attention in identifying and valuing potential plant species that occur in their agroforest gardens is still lack due to lack of knowledge about marketing aspect of the species.

Currently, the low productivity in the Batang Toru old agroforest and high economical demand has motivated some farmers to rejuvenate their old agroforest garden. Replanting method is one of the options chosen by the Batang Toru farmers in rejuvenating or 
enhancing the value of their agroforest. Farmers aware that replanting economically valuable local species (e.g. timber trees, fruit trees), in their old agroforest system, could diversify their' source of income without changing much the vegetation structure that has been formed in the agroforest garden and provide healthy environment to the nature surrounds it.

Problems that encountered by the Batang Toru farmers in replanting method mostly related to tree selection, seedlings availability and domestication technique per species. Hence, training on designing agroforest garden was given to Batang Toru farmers with focus on tree selection and the domestication technique in replanting. The training was conducted in Hutagurgur (13 Nov 2006, 15 participants, 5 females and 10 males), WEK1 (14 Nov 2006, 24 male participants), Sibulan-bulan (15 Nov 2006, 19 participants; 8 females and 11 males) and Sitandiang (16 Nov 2006, 13 male participants). The training was canceled for Aek Nabara due to bad access (road) to the area.

Group discussion, field visit and sharing experience with farmer from other area were conducted during the training to improve farmers knowledge in managing their agroforest garden into more productive and market oriented garden. We invited successful local cacao farmer (Lamlam Tarigan) to share his knowledge and skills in managing cacao simple agroforest garden (3-5 species). ICRAF staffs facilitated the training process and also shared results from demonstration plots that have been tested in other ICRAF site.

As the training was part of the habitat orangutan conservation program, some conservation issues were also stressed particularly the one that related to the advantages in having an agroforest garden than monoculture garden, i.e. agroforests provide diverse source of income and by the same time provide healthy environment for all living creatures surrounds it.

\section{Tree selection in replanting technique of less productive agroforest garden}

Farmers are keen in learning more about the issues developed during the discussion sessions in the training. In the first discussion session, participants were split into 3 small groups (consisted of 3-6 persons/group, 3 small groups/village). Each small group, facilitated by ICRAF staff, discussed some issues related to:

(i) Tree species selection for replanting and reasons why farmer choose that species.

(ii) Obstacles that will be encountered by farmers if they selected certain tree species for replanting their agroforest garden.

Unfortunately this first discussion session only possible to be conducted in Sibulan-bulan, WEK1 and Hutagurgur, the discussion couldn't be conducted in Sitandiang due to time limitation. There was only 1 big discussion in Sitandiang that covered all discussion subjects (tree selection, obstacles in replanting old agroforest garden, and gross benefit calculation that possibly can be gained if they have diverse species products in their garden).

Initiating the discussion, farmers were asked to choose 10 most preferable tree species as their source of livelihood from agroforest garden. From those 10 selected tree species, through small group discussion, farmers were asked to complete information per species on: (i) species uses, (ii) availability of the species in their garden?, (iv) was the species planted?, (v) where was the origin of the seeds or seedlings of the planting material?, (vii) main 
problems in species domestication. Farmers of all villages chose the tree species as listed below:

a) Most favorite commodities (chosen by all groups in all villages) in the area: in more lowland area: rubber (Hevea brasiliensis), cacao (Theobroma cacao), durian (Durio zibethinus), in more highland: aren (Arenga pinnata for sugar production) and rubber.

b) Second rank commodity (chosen by 1 to 3 small groups in 1 to 2 villages): banana, rambutan, petai, kulit manis, jengkol, kelapa, kemiri, kueni, manggis.

c) Third rank commodity (chosen by 1 small group in 1 village): chilli, orange (Citrus spp.), coffee (Coffea robusta), langsat (Lansium domesticum), nilam (Pogostemon cablin), pinang (Areca catechu), rattans, aren in lowland area (for alcoholic beverage production).

From the first discussion session, it is obviously seen that farmers in Batang Toru area still have high dependency to the agroforest for food security, fuel (firewood) and sources for daily cash-income. In order to enhance the economical value of the garden, farmers plan to replace trees that were not productive anymore with new trees. Hence, farmers will select trees by the strategy developed during the discussion:

(i) Besides rubber, Batang Toru farmers prefer to plant fruit tree species in their garden than timber tree species.

(ii) Farmers tend to select species that has been commonly planted in the area and has clear market.

Obstacles that will be encountered by farmers if they selected certain tree species for replanting their agroforest garden:

1. Seedling availability

2. Lack of information on species biophysical compatibility (light tolerance status, soil compatibility, altitude requirement, allelopathic with other species, effective and efficient spacing)

\section{Lack of information on species maintenance technique (pruning and fertilizing)}

Based on the discussion, farmers are still maintaining species that regenerate naturally in their garden (e.g. aren and rattans) and harvesting its products for their additional income. For replanting, farmers usually collect seedlings from other area and planted them in their garden by the sisipan (gap replanting method), other farmers bought the seedlings. For instance, some farmers that are located near the rubber estate plantation (PTPN III), bought rubber seedlings from the estate plantation. Other tree species that were also bought by the farmers for its seedlings: cacao, durian, orange, rambutan (Nephelium spp.), candlenut, coconut, cinnamon, beetle nut (Areca catechu), banana, and seeds of chili. Currently seedlings demand for garden rejuvenation is quite high, yet there is still no nursery to supply the demand. Therefore build tree nursery enterprise to fulfill seedling demand for replanting will be a promising new livelihood option for the farmers.

In the second discussion session, farmers were grouped in only 1 group per village and were introduced with gross benefit calculation that possibly can be gained if they have diverse species products in their garden. This session was conducted by the objective to increase 
farmers' awareness in the importance to notice the economical aspect in tree selection. Initiating the discussion, farmers were asked to describe the general condition of their agroforest garden by listing 5-10 tree species that are commonly harvested. Farmers were also requested to provide information per tree species that were selected on (i) marketable product of the species, (ii) current market price, (iii) average production per tree per year, (iv) harvesting age, (v) productive cycle, (vi) number of trees per hectare. From those information, the income per tree per year (= market price $\mathrm{x}$ production per tree per year), income per year per ha (= income per tree per year $\mathrm{x}$ number of trees per ha), and tree value (=market price $\mathrm{x}$ average production per tree per year $\mathrm{x}$ productive cycle) were calculated as seen in the appendix 6 .

From the Table in Appendix 6, it is clear that farmers tend to plant more trees that may have a low value but are able to provide weekly income, e.g. rubber. Though, durian and aren seems the most promising source of income but farmers only planted the trees with low number in their garden due to (i) fruit tree species can only be harvested 1 times per year, while farmers need cash income at least 1 times a week, while (ii) difficulty of harvesting technique becoming the main constraint to develop aren in the area. In summarize, based on the discussion in this session, Batang Toru farmers preferred these criteria for tree selection:

1) Trees provide weekly income continuously in 10-20 years

2) Short harvesting age (preferably 3-5 years)

3) Simple in its harvesting method

4) Simple in its maintenance

5) Seedlings are available. After farmers select the species that they going to develop then they will look for seedling availability. If farmers couldn't found it in their area, they willing to look for in other places and willing to buy the seedling.

\section{Agroforest management}

Another discussion session was also held with focused more to share knowledge and ideas on agroforest management practice that could lead to more productive agroforest garden. Local farmer (Lamlam Tarigan) who comes from Karo district in North Sumatra province, was also invited as key speaker in the discussion. He is one of the successful cacao farmers in his village. He shared his knowledge on how importance to notice plants maintenance (e.g. fertilizing, pruning, regulating space) to enhance tree productivity. Plants will produce more if it is well maintain. He also mixed the cacao plants with other fruit tree species (avocado, durian, rambutan) to diversify his income from his $3 / 4$ ha land. He recommended Batang Toru farmers to maintain diverse products in their garden to counter the price instability of 1 single agricultural commodity. After the discussion, field visit was also conducted to show the maintenance practice that has been applied by Mr. Lamlam Tarigan to increase his cacao garden productivity (e.g. pruning techniques).

Issues raised during the discussion that related to garden management mostly about: (i) technique in applying spacing in the old agroforest garden, (ii) species compatibility with other species and biophysical condition (tree selection), (iii) technique in garden rejuvenation, (iv) maintenance technique that should be applied to the agroforest garden in order to increase its productivity. 
During the discussion, ICRAF staffs also shared their experience on techniques to rejuvenate old agroforest garden by various scenarios. Rejuvenation technique for old agroforest maybe conducted in 2 scenarios:

1. Scenario 1: rejuvenate by clear cut method

The scenario usually applied if farmers still own other land that can be used to fulfill their cash-income needs. Farmers usually cut all trees that occur in the area. Regulating the space between new trees is easier by this scenario, but the cost to rejuvenate the garden by this scenario is higher than the scenario 2 .

If farmers applied this rejuvenation scenario to their garden, farmers may plant rubber trees with space $3 \mathrm{~m} \times 6 \mathrm{~m}$ as seen in Figure 6., which also known as the stripe method (metode gawangan). Weeding only apply in the radius $1 \mathrm{~m}$ from the trees and let the other $4 \mathrm{~m}$ row filled with

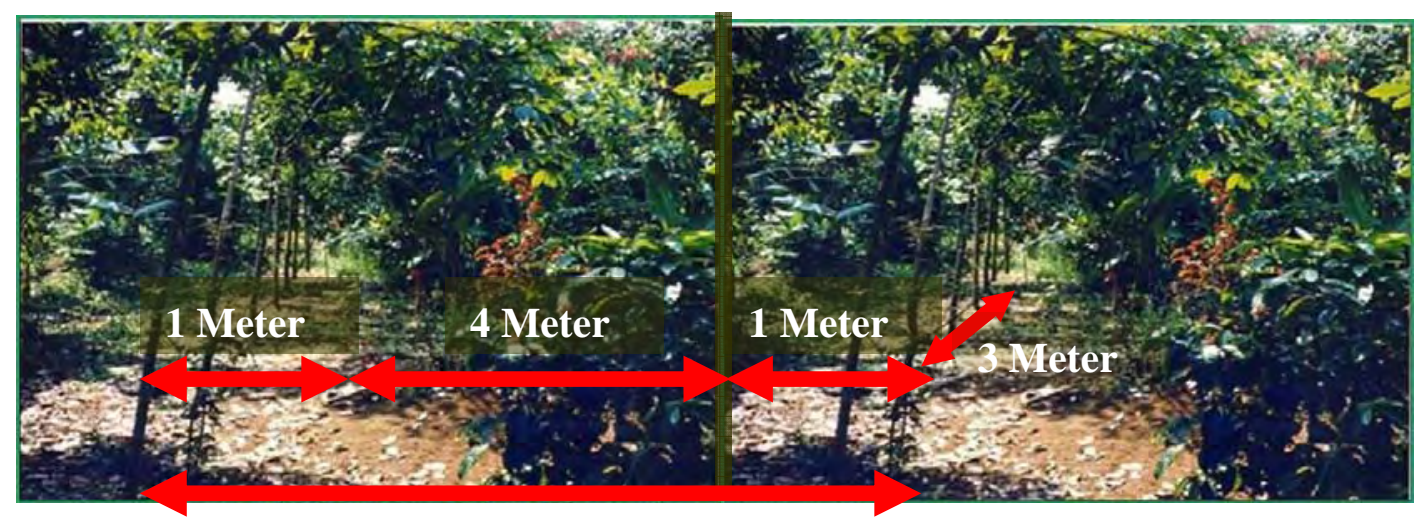

6 Meter

Figure 6. Rubber tree spacing alternative technique in garden rejuvenation by clear cut method

2. Scenario 2: rejuvenate by replanting method

This method is usually applied by planting tree seedling on a canopy gap. Knowledge on tree-climate-soil compatibility (trees with light demanded, shade demanded, intermediate, slow growing, fast growing), per species need to be learned before farmer plant the seedling. The knowledge can be learned by observing its growth and climate condition in its natural occurrence. Gap size will play major role in providing light, nutrition and water for the seedling growth.
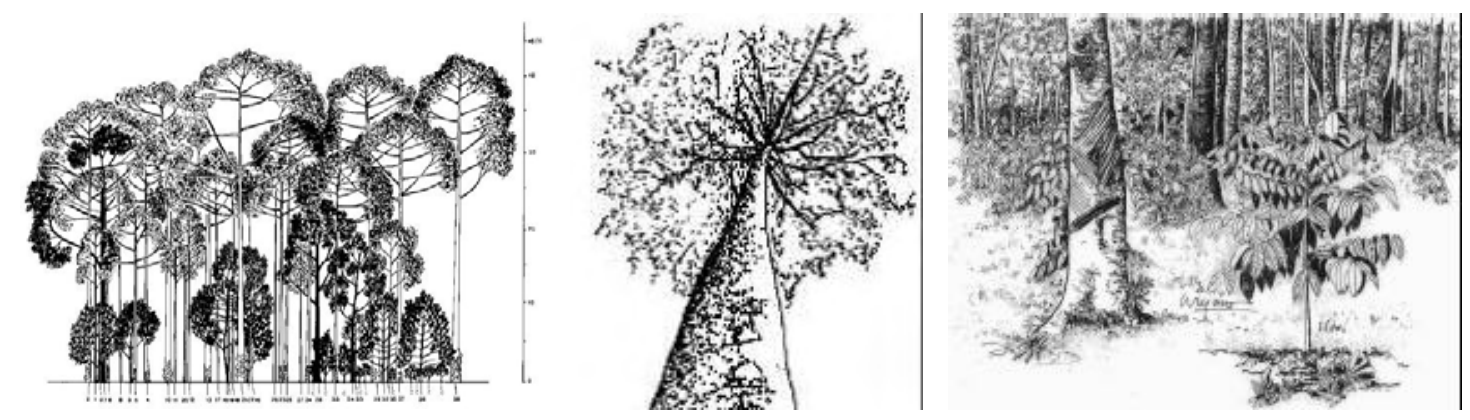

Figure 7. Example of scenario 2 replanting method based on the size of the gap and tree crown. 


\section{Recommendation}

Replanting method has been done by farmers for years, however farmers were still encountered some problems related to tree selection and knowledge for its domestication techniques (propagation and maintenance). From the discussion, some issues were recommended in relation with enhancing the economic value through replanting the current agroforest garden in Batang Toru area:

1. Tree selection: to select important tree species that should be seen from market and treeclimate-soil compatibility (trees with light demanded, shade demanded, intermediate, slow growing, fast growing), which will relate with technique in rejuvenating garden or replanting the garden.

2. Distance between plants need to be noticed because it play major role in the tree productivity

3. Tree maintenance (pruning, thinning, fertilizers if possible) need to be apply more frequently to ensure satisfied productivity.

4. Seedlings' quality is the essential part of the replanting activity that needs to be notified.

5. Nursery needs to be developed for the preferable tree species for garden replanting. Propagation techniques need to be introduced for each type of species that are going to be developed. 


\section{Appendix 3. Training on rubber pest and disease handling in agroforests in Batang Toru area}

Latex productivity from rubber trees is greatly influenced by plant vigor. If rubber trees are not in its vigor condition, it will easily be infected by pests and diseases that imply to the decrease of its latex productivity. Pests and diseases are potentially occurs in all stages of trees life form and all part of tree (roots, trunk/branches, tapping panel, leaves). Since the plant grew in the nursery, plants maintenance needs to be noticed. Fungi and other diseases in the tapping panels, and also the white rot root fungi maybe the potential threat for the rubber trees that could decrease the latex production in the area. Trees that were infected by pests or diseases will also increase costs for garden maintenance that will imply to the decreased farmer's income. Therefore, farmers knowledge in identifying pests attacked or diseases infection at the earliest stage/symptoms need to be enhanced via training in order to sustain latex production and farmer's income.

Hence, a one-day training that combining in class session with field visit, was conducted in 3 project focused village (Hutagurgur, WEK1 and Sibulan-bulan). The objective of the training: (i) identify potential rubber pest and diseases in rubber agroforest in the area; (ii) enhance farmers' skills and knowledge in handling pests and diseases attack to rubber trees in their agroforest garden. During the training session, the trainer, pests and diseases specialist from Sungai Putih Rubber Research Institute (Sujatno), assisted farmers to identify the current rubber pest and diseases in the area, and recommended its effective curative and preventive handling. Discussion on rubber pest/disease identification and handling was leaded by the trainer. Participants in the trainings were:

a. WEK1 (17 April, 15 male participants from WEK1 and 10 male participants from Aek Nabara).

b. Hutagurgur (18 April, 10 males and 3 females).

c. Sibulan-bulan (19 April, 7 males and 12 females).

Issues that were discussed during the training covered these aspects of rubber pests and diseases:

1. Symptoms of infected trees

2. Economical loss from garden with infected trees

3. Factors that affected the diseases and trees spreading

4. Preventive and Curative steps

From the field observation by the farmers and the trainer, rubber diseases were more common to be encountered than pests. Rubber diseases that usually occur in rubber trees in Batang Toru area also occur in other area in Indonesia, i.e.:

1. Root disease, i.e. White Root Rot, Red Root Rot. Root diseases will reduced ca. $>40 \%$ of latex production per area

2. Tapping panel disease, i.e. Black Thread, Mouldy Rot, Bark Nekrosis, Brown Blast. Tapping panel disease will reduced ca. $>40 \%$ of latex production per area. 
3. Trunk/branches, i.e. Pink Disease, Sapstain fungus. Trunk/branches trees will reduced ca. $>10 \%$ of latex production per area

4. Leaves disease, i.e. Oidium, Colletotrichum, Corynespora, Helminthosporium, Microcylus. Leaves disease will reduced ca. $>30 \%$ of latex production per area

Recommendations for preventive or curative handling for the pests and diseases infection:

1. Rubber disease infection can be cured or reduced by these methods:

口 Culture technique (sanitation during land preparation, etc)

a Environment manipulation (creating environment with good aeration/humidity, adding predator)

a Chemical treatment (pesticides, fungicides or herbicides)

2. Prevention steps need to be emphasized since the plant in the nursery, the land clearing stage, the planting stage, the plant maintenance stage. All potential hosts for rubber pests and diseases (e.g. rotten roots) need to be cleared from the area.

3. Used only healthy seedlings for plantation

4. Plant vigorous need to be noticed and maintained by regular fertilizing activity

5. Do not over tapping the rubber trees. Rubber trees are recommended to be tapped 1 times per 2 days.

6. It is necessary to form a forum to discuss the prevention and curative steps to handle pests and diseases encounter in the area. Extension officers role play big role in giving more intense facilitation to the farmers through the forum. 


\section{Appendix 4. Training on rubber tapping management in agroforest in Batang Toru area}

Tapping rubber trees means cutting latex vessels in tree bark to harvest the latex. Method for rubber tapping was selected by considering the low costs, maximum and sustain production. On the other hand, farmers only consider maximum production and ignoring its sustainable production. Therefore farmers usually over tapped their rubber trees that has shortened tree productivity duration and can caused trees die easily.

Most of rubber trees in Batang Toru region are old trees that will be rejuvenated, therefore farmers ignore the standard of tapping technique. Nevertheless, farmers' awareness on the urgency in applying standard tapping technique needs to be enhanced in order to sustain latex productivity in the area. Hence, a one day rubber tapping training session was conducted in the Batang Toru area by combining in-class session with field practice session. The main objective of the rubber tapping training is to increase farmer awareness in improving their way of tapping rubber in order to sustain theirs latex production and income. Basic knowledge and standard practice of rubber tapping management was given during the training session. Standard rubber tapping technique in the plantation was used as basic information given in this training. Theory in class session was given by ICRAF staffs while the local trainer (Arifin Khaeran, head of LPM of Sibabangun subdistrict, Central Tapanuli) leaded the field practice. The rubber tapping training was conducted in 5 villages:

1. Sibulan-bulan (29 persons, 15 males and 14 females),

2. WEK I (23 participants, all males)

3. Hutagurgur (25 participants, 17 males and 8 females).

4. Aek Nabara (10 male participants)

5. Sitandiang (19 male participants)

All the participants were eager to learn the techniques given by the local trainers. Based on the field observation and discussion during the training, problems with the tapping method applied by the Batang Toru farmers:

a. Irregular tapping direction and slope

b. Tapping panel direction received less attention (it should be faced to the North-South)

c. Less attention on the tapping thickness. If the bark is tapped too thick, it will slow down the bark recovery process.

d. Tapping intensity is too high (tapped everyday, and more than 1 cutting per trees)

e. Distance between tapped strips is too wide.

Issues that were discussed during the in-class session:

1. Advantages and disadvantages of tapping method that was recommended by the Rubber Research Institute and the local tapping method

2. Fertilizers to enhance latex productivity

3. Stimulants to enhance latex productivity 
4. Distance between trees that good for rubber trees growth and could enhance the latex productivity

While on the field practice session that was leaded by the local trainer, mostly about:

(i) Steps to open new tapping panel

(ii) Standard tapping technique (half trunk (s/2), with no interval between tapping strip)

(iii) Standard tapping intensity 1 times per 2 days

Recommendations from the training:

1. Farmers need to follow the standard tapping technique to sustain their latex productivity, i.e. tapping from left to right, $1 / 2$-spiral per 2 days with less than $2 \mathrm{~mm}$ tapping thickness.

2. Fertilizers need to be applied to the tapped trees at least 2 times per year. 


\section{Appendix 5. Information collected during the sugar palm training}

\begin{tabular}{|c|c|c|}
\hline Villages & Aspects & Information collected \\
\hline \multirow[t]{3}{*}{ Sitandiang } & Domestication & None \\
\hline & $\begin{array}{l}\text { Harvest and Post } \\
\text { Harvest Handling }\end{array}$ & $\begin{array}{l}\text { Farmers used coconut to substitute the palm oil to be added to } \\
\text { nira during aren cooking process. } \\
\text { Tube sanitation still receive less attention from the farmers } \\
\square \quad \text { Fuel wood is becoming the potential problem in the future } \\
\text { because the farmers have had to go to far from the village to } \\
\text { get the fuel wood to cook the nira for aren sugarpalm. } \\
\square \quad \text { Approximately, } 4.5 \mathrm{~kg} \text { sugarpalm/day produced. }\end{array}$ \\
\hline & Marketing & $\begin{array}{l}\text { Current price of aren sugarpalm in the village is Rp 6000/kg. } \\
\text { While in the nearest weekly market (Sipirok, } 15-20 \mathrm{~km} \text { far } \\
\text { from Sitandiang) is Rp 6500-7000/kg. } \\
\text { Farmers, who don't have any dependency to the traders at } \\
\text { village level, usually sell their sugarpalm to Sipirok market. } \\
\text { Village traders come from the nearest village (i.e. Bulu Mario) }\end{array}$ \\
\hline \multirow[t]{3}{*}{ Aek Nabara } & Domestication & $\begin{array}{l}\text { Some farmers were asking about method to domesticate sugarpalm } \\
\text { and the characteristic of the superior aren trees. }\end{array}$ \\
\hline & $\begin{array}{l}\text { Harvest and Post } \\
\text { Harvest Handling }\end{array}$ & $\begin{array}{l}\text { Fuel wood is not considered as problems by the farmers. } \\
\text { Farmers were not interested with palm sugar because of the } \\
\text { sophisticated procedure in producing it. } \\
\text { Farmers were not directly cooked the nira soon after they } \\
\text { collected it from the tree. Farmers usually would wait 2-3 days } \\
\text { to cook the nira, therefore they put material (root of raru) to } \\
\text { conserve the nira and also they warmed the nira. }\end{array}$ \\
\hline & Marketing & $\begin{array}{l}\text { Current price of aren sugarpalm is Rp 6000/kg. } \\
\text { Almost all the farmers in this village have high dependency to } \\
\text { the traders (they own some money to the traders for their daily } \\
\text { need), therefore they have to sell the aren sugarpalm they } \\
\text { produce to certain toke where they have dependency on. }\end{array}$ \\
\hline \multirow[t]{3}{*}{ Bulu Mario } & Domestication & $\begin{array}{l}\text { Farmers want a counseling forum that can give them information } \\
\text { on how to domesticate aren trees. Counseling on post harvest } \\
\text { handling has been conducted in this village by the subdistrict } \\
\text { extension agents; hence the farmers' knowledge on harvesting and } \\
\text { handling the post harvest process is better compare to the Aek } \\
\text { Nabara and Sitandiang villagers. }\end{array}$ \\
\hline & $\begin{array}{l}\text { Harvest and Post } \\
\text { Harvest Handling }\end{array}$ & $\begin{array}{l}\text { Production per village is 1-2 ton sugarpalm/week produced by } \\
\text { ca.150 HH. } \\
\text { Palm sugar potential and process has been introduced in this } \\
\text { village by training that was conducted in the subdistrict office } \\
\text { (Sipirok sub district). }\end{array}$ \\
\hline & Marketing & $\begin{array}{l}\text { Current price of aren sugarpalm is Rp 6000/kg; } \\
\text { There were } 15 \text { traders in Bulu Mario village and all are Bulu } \\
\text { Mario villagers. } \\
\text { Marketing aspect was identified by the farmer as the main } \\
\text { constraints in gaining good sugarpalm quality. } \\
\text { Village level traders don't have any pressure from other } \\
\text { traders at higher level. }\end{array}$ \\
\hline
\end{tabular}


Appendix 6. Estimated agroforest productivity per village based on FGD results in the agroforest management training

\begin{tabular}{|c|c|c|c|c|c|c|c|c|c|c|c|}
\hline \multirow[b]{2}{*}{ VULAGE } & \multirow[b]{2}{*}{ TREE SPECIES } & \multicolumn{9}{|c|}{ CURRENT SITUATION (NOVEMBER 2006) } & \multirow[b]{2}{*}{$\begin{array}{l}\text { Tree Value } \\
\text { (Market price is } \\
\text { assumed to be } \\
\text { stable over the } \\
\text { productive year) }\end{array}$} \\
\hline & & $\begin{array}{l}\text { Marketable } \\
\text { product }\end{array}$ & $\begin{array}{l}\text { Market price } \\
\text { per unit } \\
\text { production }\end{array}$ & $\begin{array}{c}\text { Unit } \\
\text { production }\end{array}$ & $\begin{array}{l}\text { Average } \\
\text { Production } \\
\text { per } \\
\text { tree/year } \\
\text { (unit } \\
\text { production } \\
\text { /tree) }\end{array}$ & $\begin{array}{l}\text { Estimate Income } \\
\text { per tree/year }\end{array}$ & $\begin{array}{l}\text { Harvesting } \\
\text { age (years) }\end{array}$ & $\begin{array}{c}\text { Productive } \\
\text { cycle } \\
\text { (years) }\end{array}$ & $\begin{array}{c}\text { Number } \\
\text { of } \\
\text { trees/ha }\end{array}$ & $\begin{array}{l}\text { Estimate Income } \\
\text { per year/ha }\end{array}$ & \\
\hline \multirow{7}{*}{ HUTA GURGUR } & Aren (Arenga pinnata) & $\begin{array}{l}\text { Tuak } \\
\text { (traditional } \\
\text { beverage) }\end{array}$ & Rp $2,000.00$ & Bottle & 1000 & $\operatorname{Rp} 2,000,000.00$ & 10 & 3 & 5 & Rp 10,000,000.00 & Rp 6,000,000.00 \\
\hline & Banana (Musa spp.) & Fruit & Rp 20,000.00 & Bunch & 1 & Rp $\quad 20,000.00$ & 1 & 5 & 10 & Rp $\quad 200,000.00$ & Rp $\quad 100,000.00$ \\
\hline & Cacao (Theobroma cacao) & Fruit & Rp 9,000.00 & Kilogram & 6.4 & Rp $\quad 57,600.00$ & 3 & 10 & 30 & Rp $1,728,000.00$ & Rp $\quad 576,000.00$ \\
\hline & Durian (Durio zibethinus) & Fruit & Rp 2,000.00 & Fruit & 100 & $R p \quad 200,000.00$ & 10 & 40 & 5 & Rp $\quad 1,000,000.00$ & Rp 8,000,000.00 \\
\hline & $\begin{array}{l}\text { Jengkol (Archidendron } \\
\text { jiringa) }\end{array}$ & Fruit & Rp 6,000.00 & $\begin{array}{l}\text { Can (1 can } \\
=10 \\
\text { kilogram) }\end{array}$ & 3 & $18,000.00$ & 3 & 15 & 20 & $360,000.00$ & $270,000.00$ \\
\hline & Petai (Parkia speciosa) & Fruit & Rp 3,000.00 & $\begin{array}{l}\text { Bunch (1 } \\
\text { bunch = 5 } \\
\text { strips) }\end{array}$ & 25 & $75,000.00$ & 10 & 20 & 3 & $225,000.00$ & $\operatorname{Rp} 1,500,000.00$ \\
\hline & & & & & & & & & 323 & $R p 17,609,000.00$ & \\
\hline \multirow{7}{*}{ WEK 1} & Cacao (Theobroma cacao) & Seed & Rp 8,000.00 & Kilogram & 1 & $\mathrm{Rp} \quad 8,000.00$ & 3 & 15 & 50 & Rp $\quad 400,000.00$ & Rp $\quad 120,000.00$ \\
\hline & Durian (Durio zibethinus) & Fruit & $\mathrm{Rp} \quad 3,000.00$ & Fruit & 66.7 & $\mathrm{Rp} \quad 200,100.00$ & 10 & 50 & 5 & Rp $\quad 1,000,500.00$ & $\operatorname{Rp} 10,005,000.00$ \\
\hline & $\begin{array}{l}\text { Jengkol (Archidendron } \\
\text { jiringa) }\end{array}$ & Fruit & Rp 10,000.00 & $\begin{array}{l}\text { Can (1 can } \\
=10 \\
\text { kilogram) }\end{array}$ & 3 & $30,000.00$ & 3 & 20 & 5 & $150,000.00$ & $600,000.00$ \\
\hline & $\begin{array}{l}\text { Mangostan (Garcinia } \\
\text { mangostana) }\end{array}$ & Fruit & Rp $1,000.00$ & Kilogram & 50 & $50,000.00$ & 10 & 50 & 15 & $750,000.00$ & Rp $2,500,000.00$ \\
\hline & Petai (Parkia speciosa) & Fruit & Rp 3,000.00 & $\begin{array}{l}\text { Bunch (1 } \\
\text { bunch = 5 } \\
\text { strips) }\end{array}$ & 100 & Rp $300,000.00$ & 10 & 20 & 5 & Rp $1,500,000.00$ & Rp 6,000,000.00 \\
\hline & Rubber (Hevea brasiliensis) & Latex & Rp 5,500.00 & Kilogram & 3.2 & $17,600.00$ & 10 & 25 & 200 & Rp 3,520,000.00 & $440,000.00$ \\
\hline & & & & & & & & & 280 & Rp $7,320,500.00$ & \\
\hline
\end{tabular}


Appendix 6. (continued)

\begin{tabular}{|c|c|c|c|c|c|c|c|c|c|c|c|}
\hline \multirow[b]{2}{*}{ VULAGE } & \multirow[b]{2}{*}{ TREE SPECIES } & \multicolumn{9}{|c|}{ CURRENT SITUATION (NOVEMBER 2006) } & \multirow[b]{2}{*}{$\begin{array}{l}\text { Tree Value } \\
\text { (Market price is } \\
\text { assumed to be } \\
\text { stable over the } \\
\text { productive year) }\end{array}$} \\
\hline & & $\begin{array}{l}\text { Marketable } \\
\text { product }\end{array}$ & $\begin{array}{l}\text { Market price } \\
\text { per unit } \\
\text { production }\end{array}$ & $\begin{array}{c}\text { Unit } \\
\text { production }\end{array}$ & $\begin{array}{c}\text { Average } \\
\text { Production } \\
\text { per } \\
\text { tree/year } \\
\text { (unit } \\
\text { production } \\
\text { /tree) } \\
\end{array}$ & $\begin{array}{l}\text { Estimate } \\
\text { Income per } \\
\text { tree/year }\end{array}$ & $\begin{array}{c}\text { Harvesting } \\
\text { age } \\
\text { (years) }\end{array}$ & $\begin{array}{c}\text { Productive } \\
\text { cycle } \\
\text { (years) }\end{array}$ & $\begin{array}{l}\text { Number } \\
\text { of } \\
\text { trees/ha }\end{array}$ & $\begin{array}{l}\text { Estimate Income } \\
\text { per year/ha }\end{array}$ & \\
\hline \multirow{5}{*}{$\begin{array}{l}\text { SIBULAN- } \\
\text { BULAN }\end{array}$} & Beetle nut (Areca catechu) & Seed & Rp $3,500.00$ & Kilogram & 9 & Rp $\quad 31,500.00$ & 3 & 20 & 1 & $31,500.00$ & Rp 630,000.00 \\
\hline & Durian (Durio zibethinus) & Fruit & Rp 2,000.00 & Fruit & 166.7 & Rp $333,400.00$ & 10 & 50 & 2 & $666,800.00$ & Rp 16,670,000.00 \\
\hline & Petai (Parkia speciosa) & Fruit & Rp 2,500.00 & $\begin{array}{l}\text { Bunch (1 } \\
\text { bunch = 5 } \\
\text { strips) }\end{array}$ & 50 & Rp $125,000.00$ & 10 & 20 & 10 & Rp 1,250,000.00 & Rp 2,500,000.00 \\
\hline & Rubber (Hevea brasiliensis) & Latex & $\operatorname{Rp} \quad 4,500.00$ & Kilogram & 3.2 & Rp $\quad 14,400.00$ & 10 & 30 & 150 & Rp $\quad 2,160,000.00$ & $\mathrm{Rp} \quad 432,000.00$ \\
\hline & & & & & & & & & 193 & Rp $4,348,300.00$ & \\
\hline \multirow{8}{*}{ SITANDIANG } & Aren (Arenga pinnata) & Sugarpalm & Rp 6,000.00 & Kilogram & 69.3 & Rp $415,800.00$ & 10 & 3 & 15 & Rp 6,237,000.00 & Rp 1,247,400.00 \\
\hline & $\begin{array}{l}\text { Cinnamon (Cinnamomum } \\
\text { burmannii) }\end{array}$ & Bark & Rp 2,000.00 & $\begin{array}{l}\text { Kilogram } \\
\text { (dryweight) }\end{array}$ & 1 & $2,000.00$ & 10 & 10 & 15 & $30,000.00$ & $20,000.00$ \\
\hline & Durian (Durio zibethinus) & Fruit & Rp 3,000.00 & Fruit & 66.7 & Rp 200,100.00 & 10 & 30 & 2 & $400,200.00$ & Rp 6,003,000.00 \\
\hline & Kemenyan (Styrax benzoin) & Resin & Rp $5,000.00$ & Kilogram & 5.3 & $26,500.00$ & 10 & 3 & 15 & $397,500.00$ & $79,500.00$ \\
\hline & Kopi (Coffea robusta) & Fruit & Rp 10,000.00 & Kilogram & 0.1 & $1,000.00$ & 3 & 30 & 50 & $50,000.00$ & $30,000.00$ \\
\hline & Petai (Parkia speciosa) & Fruit & Rp 2,000.00 & $\begin{array}{l}\text { Bunch (1 } \\
\text { bunch = 5 } \\
\text { strips) }\end{array}$ & 50 & Rp 100,000.00 & 10 & 30 & 2 & $200,000.00$ & Rp 3,000,000.00 \\
\hline & Rubber (Hevea brasiliensis) & Latex & Rp $4,500.00$ & Kilogram & 3.7 & $43,200.00$ & 10 & 25 & 40 & Rp $\quad 1,728,000.00$ & Rp $\quad 416,250.00$ \\
\hline & & & & & & & & & 139 & Rp $9,042,700.00$ & \\
\hline
\end{tabular}




\section{References}

Singleton, I., S. Wich, S. Husson, S. Stephens, S. Utami Atmoko, M. Leighton, N. Rosen, K. Traylor-Holzer, R. Lacy and O. Byers (eds.). 2004. Orangutan Population and Habitat Viability Assessment: Final Report. IUCN/SSC Conservation Breeding Specialist Group, Apple Valley, MN.

Sitaparasti, D. 2007. Population and distribution of the Sumatran Orangutan (Pongo abelii) in Batang Toru Watershed, North Sumatra. Thesis. Universitas Indonesia. Jakarta. 


\section{WORKI NG PAPERS IN THIS SERIES}

\section{5}

1. Agroforestry in the drylands of eastern Africa: a call to action

2. Biodiversity conservation through agroforestry: managing tree species diversity within a network of community-based, nongovernmental, governmental and research organizations in western Kenya.

3. Invasion of prosopis juliflora and local livelihoods: Case study from the Lake Baringo area of Kenya

4. Leadership for change in farmers organizations: Training report: Ridar Hotel, Kampala, 29th March to 2nd April 2005.

5. Domestication des espèces agroforestières au Sahel : situation actuelle et perspectives

6. Relevé des données de biodiversité ligneuse: Manuel du projet biodiversité des parcs agroforestiers au Sahel

7. Improved land management in the Lake Victoria Basin: TransVic Project's draft report.

8. Livelihood capital, strategies and outcomes in the Taita hills of Kenya

9. Les espèces ligneuses et leurs usages: Les préférences des paysans dans le Cercle de Ségou, au Mali

10. La biodiversité des espèces ligneuses: Diversité arborée et unités de gestion du terroir dans le Cercle de Ségou, au Mali

\section{6}

11. Bird diversity and land use on the slopes of Mt. Kilimanjaro and the adjacent plains, Tanzania

12. Water, women and local social organization in the Western Kenya Highlands

13. Highlights of ongoing research of the World Agroforestry Centre in Indonesia

14. Prospects of adoption of tree-based systems in a rural landscape and its likely impacts on carbon stocks and farmers' welfare: The FALLOW Model Application in Muara Sungkai, Lampung, Sumatra, in a 'Clean Development Mechanism' context

15. Equipping integrated natural resource managers for healthy agroforestry landscapes.

16. Are they competing or compensating on farm? Status of indigenous and exotic tree species in a wide range of agro-ecological zones of Eastern and Central Kenya, surrounding Mt. Kenya.

17. Agro-biodiversity and CGIAR tree and forest science: approaches and examples from Sumatra.

18. Improving land management in eastern and southern Africa: A review of polices.

19. Farm and household economic study of Kecamatan Nanggung, Kabupaten Bogor, Indonesia: A socio-economic base line study of agroforestry innovations and livelihood enhancement.

20. Lessons from eastern Africa's unsustainable charcoal business.

21. Evolution of RELMA's approaches to land management: Lessons from two decades of research and development in eastern and southern Africa

22. Participatory watershed management: Lessons from RELMA's work with farmers in eastern Africa.

23. Strengthening farmers' organizations: The experience of RELMA and ULAMP.

24. Promoting rainwater harvesting in eastern and southern Africa.

25. The role of livestock in integrated land management.

26. Status of carbon sequestration projects in Africa: Potential benefits and challenges to scaling up.

27. Social and Environmental Trade-Offs in Tree Species Selection: A Methodology for I dentifying Niche Incompatibilities in Agroforestry [Appears as AHI Working Paper no. 9]

28. Managing tradeoffs in agroforestry: From conflict to collaboration in natural resource management. [Appears as AHI Working Paper no. 10]

29. Essai d'analyse de la prise en compte des systemes agroforestiers pa les legislations forestieres au Sahel: Cas du Burkina Faso, du Mali, du Niger et du Senegal.

30. Etat de la recherche agroforestière au Rwanda etude bibliographique, période 1987-2003 


\section{7}

31. Science and technological innovations for improving soil fertility and management in Africa: A report for NEPAD's Science and Technology Forum.

32. Compensation and rewards for environmental services.

33. Latin American regional workshop report compensation.

34 Asia regional workshop on compensation ecosystem services.

35 Report of African regional workshop on compensation ecosystem services.

36 Exploring the inter-linkages among and between compensation and rewards for ecosystem services CRES and human well-being

37 Criteria and indicators for environmental service compensation and reward mechanisms: realistic, voluntary, conditional and pro-poor

38 The conditions for effective mechanisms of compensation and rewards for environmental services.

39 Organization and governance for fostering Pro-Poor Compensation for Environmental Services.

40 How important are different types of compensation and reward mechanisms shaping poverty and ecosystem services across Africa, Asia \& Latin America over the Next two decades?

41. Risk mitigation in contract farming: The case of poultry, cotton, woodfuel and cereals in East Africa.

42. The RELMA savings and credit experiences: Sowing the seed of sustainability

43. Yatich J., Policy and institutional context for NRM in Kenya: Challenges and opportunities for Landcare.

44. Nina-Nina Adoung Nasional di So! Field test of rapid land tenure assessment (RATA) in the Batang Toru Watershed, North Sumatera.

45. Is Hutan Tanaman Rakyat a new paradigm in community based tree planting in Indonesia?

46. Socio-Economic aspects of brackish water aquaculture (Tambak) production in Nanggroe Aceh Darrusalam.

47. Farmer livelihoods in the humid forest and moist savannah zones of Cameroon.

48. Domestication, genre et vulnérabilité : Participation des femmes, des Jeunes et des catégories les plus pauvres à la domestication des arbres agroforestiers au Cameroun.

49. Land tenure and management in the districts around Mt Elgon: An assessment presented to the Mt Elgon ecosystem conservation programme.

50. The production and marketing of leaf meal from fodder shrubs in Tanga, Tanzania: A propoor enterprise for improving livestock productivity.

51. Buyers Perspective on Environmental Services (ES) and Commoditization as an approach to liberate ES markets in the Philippines.

52. Towards Towards community-driven conservation in southwest China: Reconciling state and local perceptions.

53. Biofuels in China: An Analysis of the Opportunities and Challenges of J atropha curcas in Southwest China.

54. J atropha curcas biodiesel production in Kenya: Economics and potential value chain development for smallholder farmers

55. Livelihoods and Forest Resources in Aceh and Nias for a Sustainable Forest Resource Management and Economic Progress.

56. Agroforestry on the interface of Orangutan Conservation and Sustainable Livelihoods in Batang Toru, North Sumatra.

\section{8}

57. Assessing Hydrological Situation of Kapuas Hulu Basin, Kapuas Hulu Regency, West Kalimantan.

58. Assessing the Hydrological Situation of Talau Watershed, Belu Regency, East Nusa Tenggara.

59. Kajian Kondisi Hidrologis DAS Talau, Kabupaten Belu, Nusa Tenggara Timur.

60. Kajian Kondisi Hidrologis DAS Kapuas Hulu, Kabupaten Kapuas Hulu, Kalimantan Barat. 



\section{Who we are}

The World Agroforestry Centre is the international leader in the science and practice of integrating 'working trees' on small farms and in rural landscapes. We have invigorated the ancient practice of growing trees on farms, using innovative science for development to transform lives and landscapes.

\section{Our vision}

Our Vision is an 'Agroforestry Transformation' in the developing world resulting in a massive increase in the use of working trees on working landscapes by smallholder rural households that helps ensure security in food, nutrition, income, health, shelter and energy and a regenerated environment.

\section{Our mission}

Our mission is to advance the science and practice of agroforestry to help realize an 'Agroforestry Transformation' throughout the developing world.

\section{F U T UR E ڤै HA RY/ES T CGIAR}

A Future Harvest Centre supported by the CGIAR

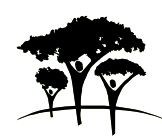

United Nations Avenue, Gigiri - PO Box 30677 - 00100 Nairobi, Kenya Tel: +254 207224000 or via USA +1 6508336645

Fax: +254207224001 or via USA +16508336646

Southeast Asia Regional Programme - Sindang Barang, Bogor 16680 PO Box161 Bogor 16001, Indonesia

Tel: +62 251625415 - Fax: +62 251625416

www.worldagroforestry.org 